\title{
STEPHANIAN FOSSIL FLORA FROM PARALIC CARBONIFEROUS DEPOSITS OF THE JESENICE AREA (SLOVENIA) AND ITS COMPARISON WITH CZECH LOCALITIES
}

\author{
Josef Pšenička ${ }^{1}$, Tea Kolar-Jurkovšek ${ }^{2}$, Stanislav Opluštil ${ }^{3} \&$ Matevž Novak $^{2}$
}

1 Palaeontological Department, West Bohemian Museum in Pilsen, Kopeckého sady 2, 30100 Pilsen, Czech Republic; jpsenicka@zcm.cz

2 Geological Survey of Slovenia, Dimičeva ul. 14, 1000 Ljubljana, Slovenia; tea.kolar@geo-zs.si, matevz.novak@geo-zs.si

${ }^{3}$ Department of Geology and Paleontology, Faculty of Science, Charles University in Prague, Albertov 6, 128 43 Prague 2, Czech Republic; oplustil@natur.cuni.cz

\begin{abstract}
This paper provides documentation of the Late Carboniferous flora of the Southern Karavanke Mountains in Slovenia that is housed in the Gornjesavski Muzej (Upper Sava Museum) in Jesenice, Slovenia. The paleoflora from this area has not been systematically documented until today. 21 fossil-species, which probably represent 17 biological species, were identified. Common species include Sigillaria brardii Brongniart, Lepidodendron dissitum Sauver, Annularia carinata Gutbier, Calamites undulatus Sternberg, Sphenophyllum oblongifolium (Germar and Kaulfuss) Unger, Acitheca polymorpha (Brongniart) Schimper and Nemejcopteris feminaeformis (Schlotheim) Barthel. Stratigraphically important are Sphenophyllum oblongifolium and Nemejcopteris feminaeformis, and based on their occurrence we can assume the studied paleoflora to be Gzhelian D (Jigulites jigulensis zone on the Russian Platform), i.e. Stephanian C.
\end{abstract}

Key words: Pennsylvanian, paleoflora, Southern Karavanke Mts., Slovenia, Jesenice

\section{INTRODUCTION}

The purpose of this paper is to document the Late Carboniferous flora of the Southern Karavanke Mountains in Slovenia, based on a collection housed in the Gornjesavski Muzej (Upper Sava Museum) in Jesenice. Preservation of the flora is comparable to the better known Late Carboniferous floras from the Austrian/Italian Carnic Alps.

Post-Variscan Carboniferous and Permian strata with fossil megafloras in Slovenia crop out in the geotectonic units of the Southern Alps and External Dinarides (Placer, 1999; Kolar-Jurkovšek and Jurkovšek, 2012). A Namurian-Westphalian or Westphalian A (Langsettian) flora was collected in the Sava Folds, and was reported already in the nineteenth century and in the first half of twentieth century by Morlot (1850), Hauer (1851), Lipold (1857, 1858), Kossmat (1913), Tornquist (1929) and Rakovec (1932). Later studies on the megaflora of the Sava Folds were published by Kolar-Jurkovšek and Jurkovšek (1985, 1986 , 1990, 2002a, 2002b, 2007, 2012).
Younger, Stephanian floras occur in the Southern Karavanke Mountains of Slovenia (KolarJurkovšek and Jurkovšek, 2012). Plant fossils from the Javorniki area were mentioned by Morlot (1850) and Stur (1886). A small flora from the Planina locality below the Golica Mt. was studied but not illustrated by Takšić (1947) and the following species were determined: Pecopteris aff. arborescens Brongniart, Alethopteris serlii Brongniart, Alethopteris grandini Brongniart, Neuropteris ovata Hoffmann, Neuropteris sp., Sphenophyllum sp., Annularia stellata (Schlotheim) Wood, Calamites rimosus Artis, Calamites sp. and Lepododendron rimosum Sternberg. Takšić (1947) compared this with the flora from certain locations in Austria and regarded it as Asturian or Early Stephanian age (highest Westphalian D or Lower Stephanian). Later, illustrations of few specimens appeared in some publications (Ramovš, 1978; Pavšič, 1995; Novak and Skaberne, 2009). Among them, a megaflora list from Gzhelian strata of the Javornik beds 
in the area north from Jesenice includes Polymorphopteris polymorpha (Brongniart) Wagner and Annularia stellata (Schlotheim ex Sternberg) Wood. Lepidodendron cf. scutatum Lesquereux and Sigillaria brardii Brongniart recorded by Ramovš (1978) should also be mentioned.

The material dealt with in the present paper originated from the Javorniki area and represents the most significant Late Carboniferous flora from the Slovenian part of the Southern Karavanke. It comprises about a hundred specimens housed in the Gornjesavski muzej in Jesenice and was collected by Jože Bedič. In addition, other specimens can be found in the collection of the Faculty of Natural Sciences and Engineering of the University of Ljubljana.

\section{GEOLOGY: LOCALITY, GEOLOGICAL SETTING, SEDIMENTARY ENVIRONMENT}

\section{Locality}

Late Carboniferous plant fossils stored in the Gornjesavski Muzej (Upper Sava Museum) in Jesenice have been found on the southern slope of the Karavanke mountains north of the city of Jesenice in NE Slovenia. Most of the specimen were collected near the village Planina pod Golico (Figure 1B) by a careful local amateur fossil collector, Mr. Jože Bedič. A thick weathering residue makes a lithostratigraphic section impossible to ascertain. However, on the basis of soil particles and gravel it is clear that the succession consists of alternating siliciclastic rocks with a predominance of quartz siltstone and fine-grained sandstone, and with subsidiary coarse-grained quartz sandstone, quartz conglomerate and shale. Plant fossils were mostly restricted to a single siltstone horizon approx. $400 \mathrm{~mm}$ thick (according to $\mathrm{Mr}$. Peternel - oral communication, August 5, 2014). Carboniferous plant remains occur also as rare elements of the otherwise large and very diverse biotic assemblages in the Gzhelian siltstones, shales and black limestones at other localities in the wider Jesenice area. The areas of Javorniški Rovt (Spodnja Počivala) (Figure 1B), Savske jame, Planina pod Golico and Hrušica are known as the richest fossil localities in the Southern Karavanke Mountains, and because of this all these localities are protected as natural heritage sites. Paleonto-
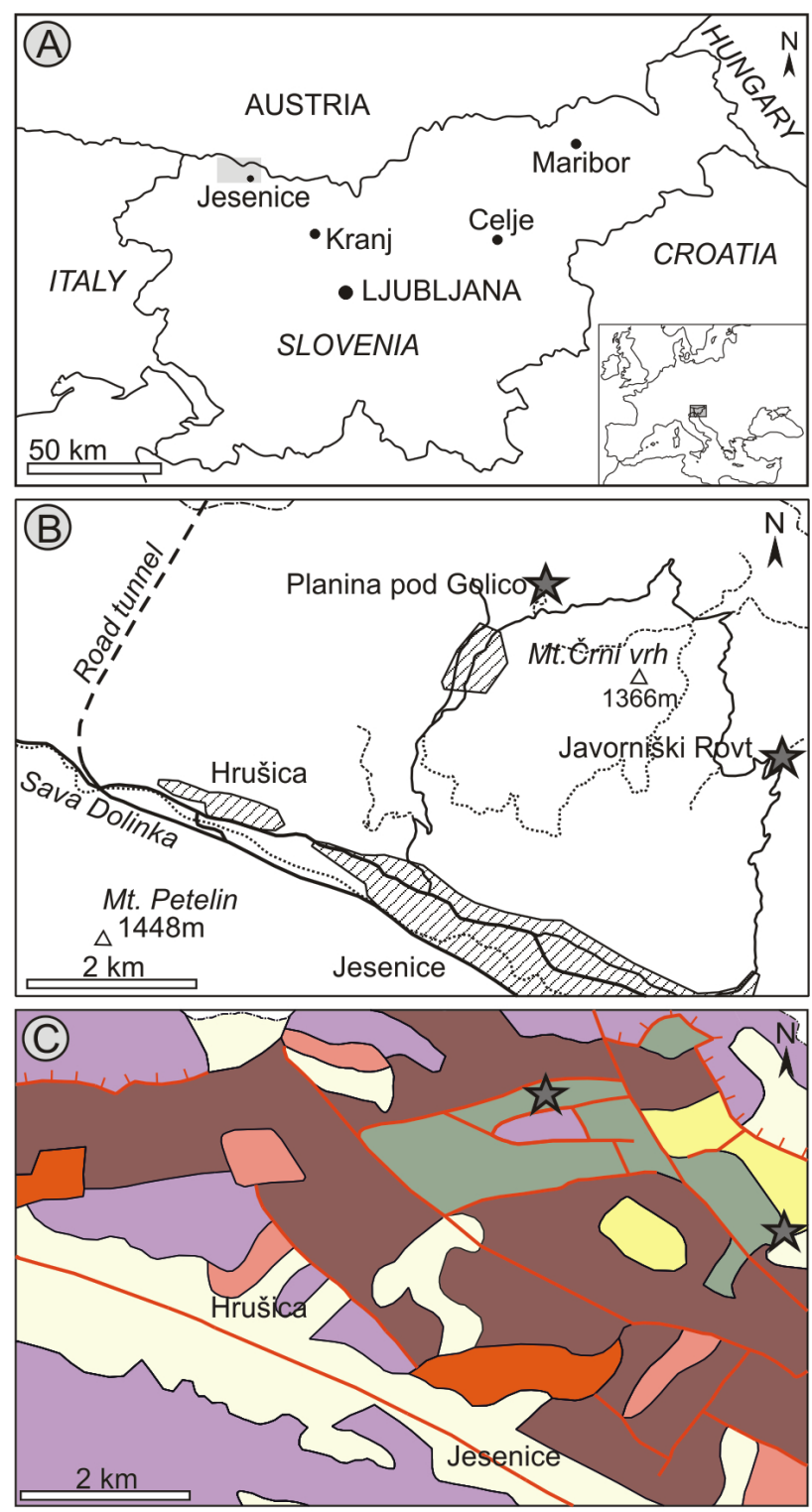

Quaternary deposits

$\square$ Eocene marlstone and siliciclastic rocks

$\square$ Triassic sedimentary and volcanic rocks

Upper Permian dolostone (Bellerophon Formation)

Middle Permian carbonate breccia (Tarvis Breccia)

Lower Permian mixed carbonate - siliciclastic rocks (Rattendorf Group and Trogkofel Formation)

Upper Carboniferous plant fossils bearing siliciclastic rocks (Auernig Formation)

色 Plant fossil localities

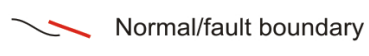

$\triangle$ Mountain top

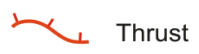

Figure 1. A) Geographic location of the study area, B) Map of localities, C) Simplified geological map. (according to Buser, 2009). 
logical studies had already begun there in the $1850 \mathrm{~s}$. The most common or significant macrofossils are bryozoans, brachiopods, corals, bivalves, gastropods, cephalopods, trilobites, and plant remains (see summary in Novak Skaberne, 2009).

\section{Geological setting}

Outcrops of the Upper Carboniferous late- to postVariscan sequence in the Southern Karavanke mountains are exposed in tectonically isolated lenses or narrow bands as a result of a strong overprint by Alpine tectonics (Buser, 1980, 2009; Jurkovšek, 1987). This, together with a thick cover of weathering residue, is the reason why detailed facies relationships and the biostratigraphic subdivision are still vague. However, the composite lithostratigraphic column displays a very similar succession compared to the Auernig Formation in the Carnic Alps (Austria/Italy), which are the morphological and orographic continuation of the Southern Karavanke Mountains and closely correspond to them in their geological structure. They both belong to the Southern Alps geotectonic unit
(Placer, 1999). The biostratigraphic subdivision and facies relationships scheme of the Auernig Formation in the Carnic Alps (e.g. Heritsch et al., 1934; Selli, 1963; Venturini, 1982; Kahler, 1986; Krainer, 1992; Krainer \& Davydov, 1998; Schönlaub and Forke, 2007) have been historically applied (as Javornik Beds) to the Southern Karavanke mountains with only minor modifications (Kochansky-Devidé and Ramovš, 1966; Novak and Skaberne, 2009).

Basal parts of the molasse-type deposits of fluvialdeltaic, coastal to shallow-marine environments unconformably overlie the Variscan flysch, flyschlike and other basement rocks. The earliest fossiliferous transgressive beds corresponding to the Auernig Formation (Figure 2) are early Kasimovian (Krevyakinian) quartz conglomerates, sandstones, siltstones, and shales with rare lenses of black limestones (Kochansky-Devidé, 1965, 1971; Novak and Skaberne, 2009).

Upper Carboniferous rocks of the broader Jesenice area (Figure 1C), described as Javornik Beds, were subdivided based on fusulinid foraminifera

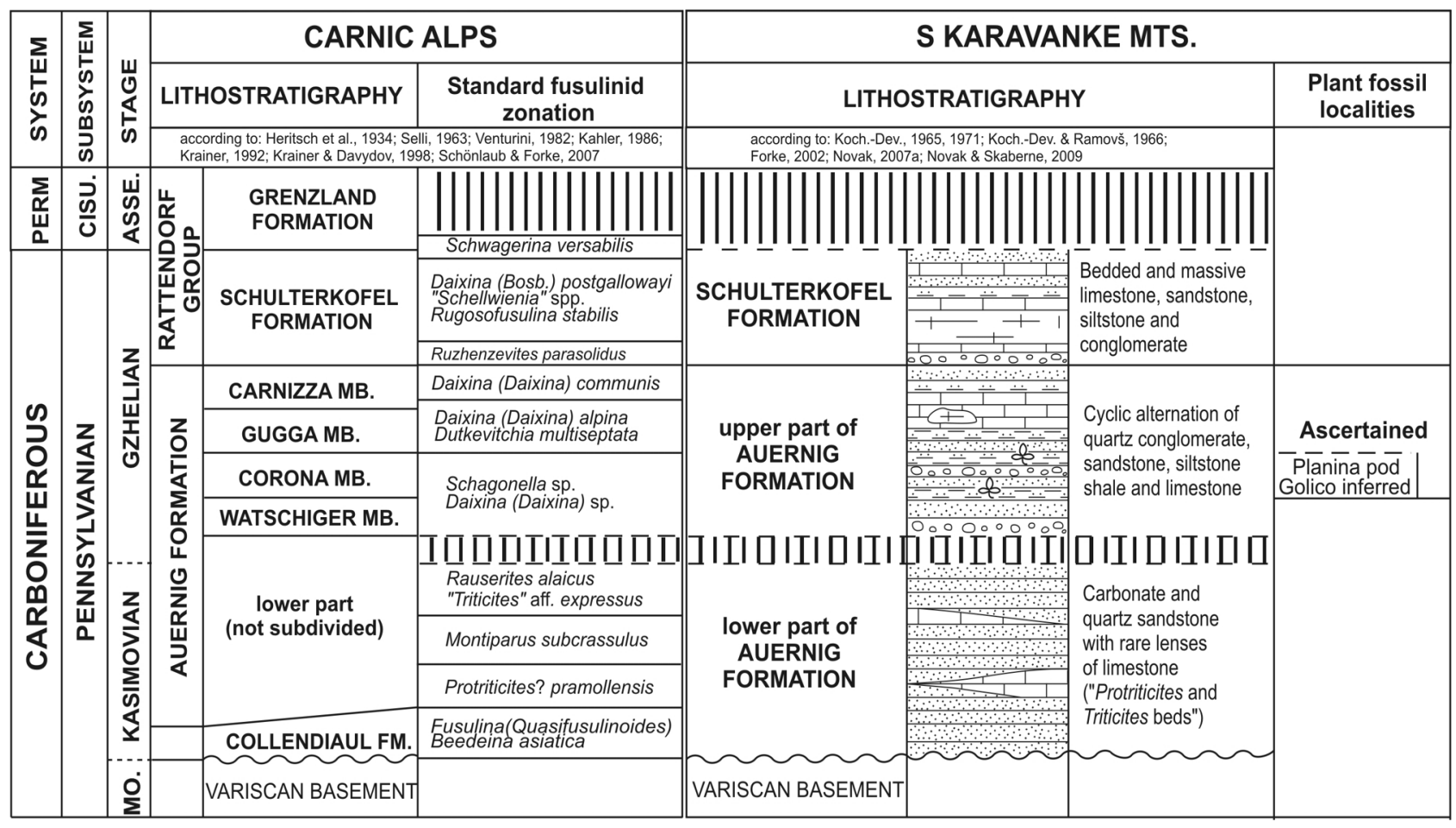

Figure 2. Upper Carboniferous lithostratigraphy of the Southern Karavanke Mountains, correlated with the Carnic Alps standard subdivisions (adapted after Novak, 2007a). 
into rocks of the Gzhelian and Orenburgian stages by Kochansky-Devidé and Ramovš (KochanskyDevidé and Ramovš, 1966; Kochansky-Devidé, 1971) (see Figure 2). The Gzhelian succession consists of quartz conglomerates and sandstones with plant remains, passing upwards into calcareous sandstones with rare fusulinids. The upper part consists of dark-grey thick-bedded limestones with thin interbeds of limestone and sandstone with a calcareous matrix. The latter is so abundant with fusulinids of the Triticites genus (T. pusillus (Schellwien) and T. cf. pseudoarcticus Rauser) that the rock was named Triticites sandstone. The thickness of the outcropping beds is approx. $20 \mathrm{~m}$, yet their total thickness is unknown.

Among the beds placed in the Orenburgian Stage by Kochansky-Devidé and Ramovš (1966), dark-grey and bluish-grey shales prevail. There is often a high content of mica and pyrite. They frequently grade to siltstones and marlstones, alternating with quartz sandstones with a quartz or calcareous matrix, and less often with quartz conglomerates. Lens-shaped massive algal limestone bodies of various sizes with algal species Anthracoporella spectabilis Pia occur between shales. Occasionally platy limestone with claystone intercalations occur, rich in phylloid algae and foraminifera. The most common among the fusulinids are Quasifusulina longissima ultima Kanmera, Rugosofusulina $[\rightarrow$ Daixina $]$ cf. alpina (Schellwien) and $R$. [ $\rightarrow$ D.] alpina antiqua (Schellwien). The thickness of the exposed beds, attributed to the Orenburgian Stage by Kochansky-Devidé and Ramovš (1966), was estimated at $170 \mathrm{~m}$. The name "Orenburgian" was used in Russia for rocks younger than Gzhelian, but older than Permian. Orenburgian as a Stage name has not been accepted by the International Commission on Stratigraphy and is therefore regarded as an equivalent to the upper part of the Gzhelian. A similar fusulinid assemblage is known from the lithologically identical Gugga and Carnizza members (upper part of the Auernig Formation) in the Carnic Alps. It can be correlated with the Daixina sokensis zone (Gzhelian E) on the Russian Platform (Kahler, 1986; Krainer and Davydov, 1998; Forke, 2002).

The Gzhelian age of the plant fossil locality at Planina pod Golico is well constrained by its position within the described succession. Considering the aforementioned outcrop condition it is highly speculative to try to define the stratigraphic level more precisely. However, based on the reported plant fossil bearing localities from the Carnic Alps (Unger, 1870; Fritz and Boersma, 1980, 1984b, 1986a, b; Fritz et al., 1990; Krainer, 1989, 1990; Fritz and Krainer, 1995, 2004, 2006, 2007), we could infer the correlation with the Corona (Krone) Member of the Auernig Formation. Mount Corona is not only the most prolific in plant fossils but also lithologically very similar to the Planina pod Golico locality. The old name of the Corona Formation, the Middle Limestone Poor Group (Mittlere kalkarme Schichtgruppe, Heritsch et al., 1934; Selli, 1963) indicates a predominantly siliciclastic succession with almost no carbonate beds and very poor marine fossil fauna which is also the case at Planina pod Golico. The suggested correlation with the Corona Member of the Auernig Formation would place the Planina pod Golico plant fossil bearing rocks below the "Orenburgian" beds of Kochansky-Devidé and Ramovš (1966) in the Gzhelian D (Jigulites jigulensis zone on the Russian Platform), i.e. Stephanian C (Krainer and Davydov, 1998) (Figure 2).

\section{Sedimentary environment}

Facies association and (micro)facies characteristics indicate that in the entire Karavanke mountains area Upper Carboniferous beds were deposited on a platform with a gently inclined ramp configuration (Novak, 2007a, b). The siliciclastic-carbonate sedimentary succession exhibits a clear cyclic transgressive-regressive depositional pattern arranged in 20-40 m thick sequences known as Auernig cyclothems (Kahler, 1955; Massari and Venturini, 1990; Krainer, 1992). Coarse-grained fluvial, coastal and/or fan-deltaic conglomerates alternate with finer-grained sandstones and bioturbated siltstones deposited under the strong influence of storm events in the lower shoreface setting and with limestone horizons mainly related to algal mound buildups in the offshore setting below the storm wave base, down to $40 \mathrm{~m}$ deep (Novak, $2007 \mathrm{~b}, 2009$ ). Based on the good state of preservation of plant fossils it can be assumed that they were transported only over short distances. They may originate in the wetland area very close to the coastal region. 


\section{SYSTEMATIC PART}

Class Lycopsida Scott, 1909

Order Lepidocarpales Thomas and Brack-Hane, 1984

\section{Family Lepidodendraceae}

Species Lepidodendron dissitum Sauver (Plate I; Plate II, Fig. 1)

To this species we assign four specimens figured here on Plate I, Figs 1-5 and Plate II, Fig. 1. They represent remains of slender branches between 10 and $20 \mathrm{~mm}$ wide preserved as impressions except the specimen on Plate I, Fig. 1 which is a compression. All the specimens possess helically arranged rhomboidal leaf cushions with rounded lateral angles and acute base and apex. The base and apex of the specimen on Plate I, Fig. 1 are slightly inflected. Leaf cushions are mostly flat or only slightly raised. The keel is straight and without striations, at least where the preservation allows details to be seen. Leaf cushions of the specimen on Plate I, Fig. 4 are about $5 \mathrm{~mm}$ high and $3 \mathrm{~mm}$ wide (ratio $\approx 1.7$ ) whereas those of the specimen on Fig. 3 are $4.4 \mathrm{~mm}$ high and $2.9 \mathrm{~mm}$ wide (ratio $3 \approx 1.6$ ). Specimens with narrower leaf cushions with more inflected lower and upper angles are shown on Plate I, Fig. 1 and Plate II, Fig. 1 . The latter has leaf cushions $8 \mathrm{~mm}$ high and only $2.4 \mathrm{~mm}$ wide having a ratio $\approx 3.3$. Such values are more typical for another Stephanian species, Lepidodendron gaudryi Renault from middle Stephanian of Commentry. However, the specimen figured by Renault has very small leaf scar and therefore we assume this is a different species. On the other hand, Wagner and Talens (1985) depicted specimens of $L$. dissitum from Stephanian
C strata of central Spain the leaf cushion ratio of which is 2.8 , which is already comparable with the values measured here. The leaf scar is located just above the lower half of the leaf cushion and is relatively large, occupying most of the width of leaf cushion. On relatively well preserved specimen (Plate I, Figs 4, 5) some leaf scars show marking which should represent a vascular bundle and parichnos. Infrafoliar parichnos markings are however, absent. The leaf scar is rhomboidal, wider than long with acute lateral angles and rounded base and subangular apex. Leaf scars of the specimen on Plate I, Fig. 2 are about $2 \mathrm{~mm}$ wide and $1.3 \mathrm{~mm}$ high (ratio $\approx 1.5$ ) whereas those of the specimen on Fig. 4 are $3.5-3.9 \mathrm{~mm}$ wide and $2.3-2.4 \mathrm{~mm}$ high (ratio $\approx 1.6$ ).

\section{Family Flemingitaceae}

Species Bergeria cf. dilata (Lindley and Hutton 1831) Álvarez-Vázquez and Wagner 2014

This species is represented only by two specimens figured on Plate II (Figs 2 and 3). They represent fragment of stem/branch with helically arranged, rhomboidal leaf cushions, apparently longer than broad, and without a differentiated leaf scar. Leaf cushions are nearly flat or slightly raised, smooth, with the broadest part in the upper third of cushion, straight (Plate II, Fig. 3) or slightly inflected base, acute apex, and rounded lateral angles (Plate II, Fig. 2). Dimension of leaf cushions of both specimens considerably differ. Specimen on Plate II, Fig. 2 possess smaller and wider leaf cushions which are around $6.0-6.1 \mathrm{~mm}$ long and $2.1 \mathrm{~mm}$ wide (ratio $\approx 2.9$ ) whereas leaf cushions of the specimen on the Plate II, Fig. 3 are much longer and narrower. Their length varies between $10.8-$

Plate I. Lepidodendron dissitum, all specimens come from Planina pod Golico locality. 1) Remains of slender branches partly 3D preserved with helically arranged rhomboidal leaf cushions. The leaf cushions are narrower in comparison with the other specimens of this species; scale bar $10 \mathrm{~mm}$; 2) Remains of slender branches with helically arranged rhomboidal leaf cushions; scale bar $5 \mathrm{~mm}$; 3) Detail of leaf cushions from figure 2; scale bar $5 \mathrm{~mm}$; 4) Remains of slender dichotomous branches; specimen No. 44, stored in drawer TJ10; scale bar $10 \mathrm{~mm}$; 5) Detail of leaf cushions from figure 4; loc. specimen No. 44, stored in drawer TJ10; scale bar $5 \mathrm{~mm}$.

Plate II. All specimens come from Planina pod Golico locality. 1) Lepidodendron dissitum, remains of slender dichotomous branches; stored in drawer TJ8; scale bar $10 \mathrm{~mm}$; 2) Bergeria cf. dilata, fragment of stem/branch with helically arranged, rhomboidal leaf cushions, apparently longer than broad, and without differentiated leaf scars; specimen No. 40, stored in drawer TJ8; scale bar $5 \mathrm{~mm}$; 3) Bergeria cf. dilata, fragment of stem/branch with helically arranged, rhomboidal leaf cushions, apparently longer than broad, and without a differentiated leaf scar. The leaf cushions of this specimen are much longer and narrower than in specimens on Fig. 2; specimen No. 42, stored in drawer TJ8; scale bar $5 \mathrm{~mm}$. 


\section{Plate I.}

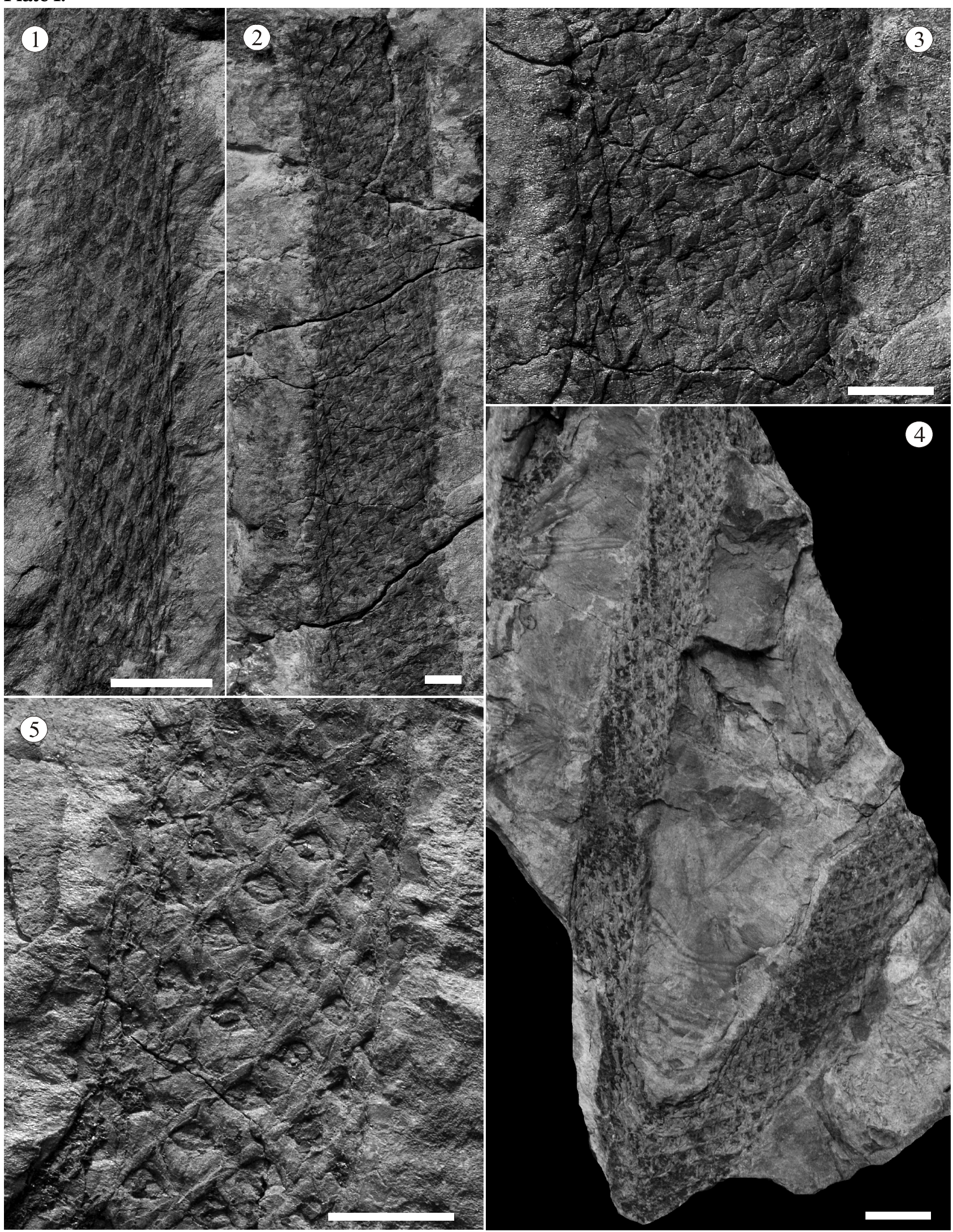




\section{Plate II.}

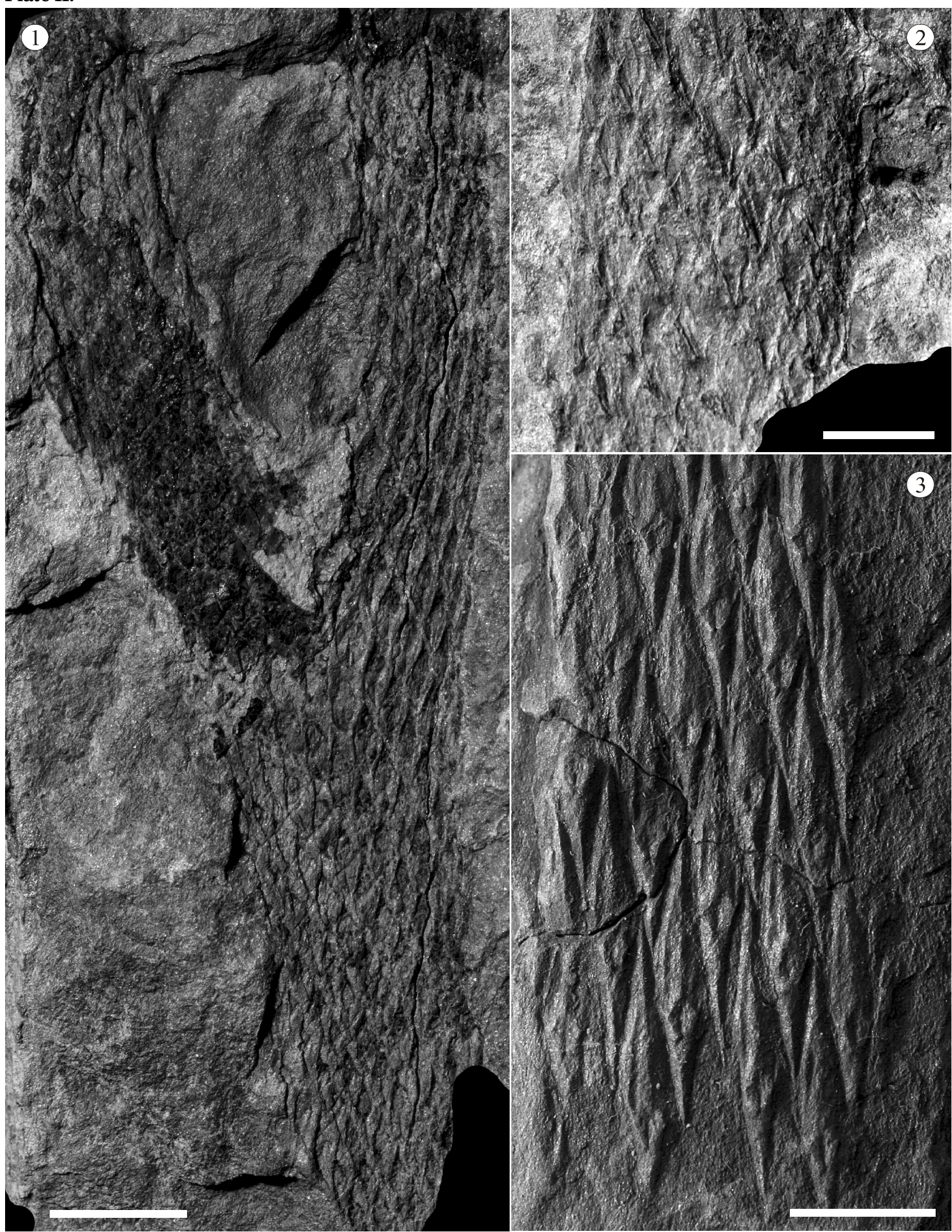


$11.5 \mathrm{~mm}$ and length is about $2.0-2.1 \mathrm{~mm}$ (ratio $\approx$ 5.6). Such differences indicate different position on the branch/stem. A lower keel is absent or only faintly marked. An upper keel is slightly raised smooth without transverse lines. A small, irregular scar marks the position of the leaf base situated just below the upper keel and slightly above the maximum width of leaf cushion. This marking represents a "false leaf scar" (Chaloner, 1967) indicating that leaf was still attached to the leaf cushion. They are usually preserved in counterparts which is in the collection. However, as stated by ÁlvarezVázquez and Wagner (2014) leaves of lepidodendrids can be seen only where the margin of the stem or branch is preserved. This is the case of the specimen on Plate II, Fig. 3 shows lateral view of leaf cushions along the branch margin to which very poorly preserved lines inserted at an angle of about $35-40^{\circ}$ are inserted. These may represent "haloes" of the original leaves attached to the leaf cushions.

Associated with the lepidodendrid remains at the locality Planina pod Golico are various forms of decorticated lycopsid remains in the Knorria state of preservation (Plates III and IV). Their determination to species level is practically impossible and even to generic level remains problematic. Knorria type of preservation, which represents deeply decorticated stems where nearly all the bark tissues are lost and only parichnos strands are present as longitudinal ridges, is known from a number of genera; for example Lepidodendron, Lepidophloios, Paralycopodites, Lepidodendropsis, Omphalophloios (Gensel and Pigg, 2009; Bek et al., 2014). The one on Plate III, Fig. 1 is preserved as an impression of about $53 \mathrm{~mm}$ wide branch showing either longitudinally oriented and helically arranged discontinuous ridges. These are accompanied by incomplete and poorly preserved leaf cushion outlines. The specimen on Plate III, Fig. 2 is a stem cast with similar discontinuous helically arranged longitudinal ridges which are about $10 \mathrm{~mm}$ long and in a helix situated $5 \mathrm{~mm}$ apart. The specimen on Plate IV is $>90 \mathrm{~mm}$ thick stem with longitudinal ridges that are oval $2 \mathrm{~mm}$ wide and 7 to $10 \mathrm{~mm}$ long. The outline of leaf cushions is not preserved; however, the surface between the vertical ridges is covered by vertically to subvertically oriented fine wrinkles resembling those typical of Asolanus camptotaenia, an arborescent lycopsid of sigillarian affinity and long stratigraphic range from Middle Moscovian ( D Duckmantian) to late Gzhelian (Stephanian C). The specimen, however, lacks leaf scars typical of that species and therefore its determination as a decorticate stage Knorria seems to be more correct, although even the formerly suggested name cannot be excluded.

\section{Family Sigillariaceae}

\section{Species Sigillaria brardii Brongniart (Plates V - XII)}

This is the most common lycopsid species in the studied collection, represented by $>20$ specimens preserved in various stages of decortication and figured on Plates V - XII. Among the best preserved undecorticated specimens are those on Plate V, Figs 1-4, Plate XI, Fig. 2 and Plate XII, Fig. 3. They show an interlocking disposition and general outline of leaf scars with surrounding fields which is typical of the "ichtyolepis" form of Sigillaria brardii. The scar with surrounding field is hexagonal, wider than higher. Scars of the specimen figured on Plate V, Fig. 2 are between 6.6 and $7.4 \mathrm{~mm}$ wide and 3.4 and $3.8 \mathrm{~mm}$ high. The scar itself has acute lateral angles and a rounded base. The apex is straight or convex. The axis which bear them is about $55 \mathrm{~mm}$ wide. Larger leaf scars occur on the specimens on Plate XI, Fig. 2 and Plate XII, Fig. 3. They are $10.8 \mathrm{~mm}$ wide and $3 \mathrm{~mm}$ high in the former and $10 \mathrm{~mm}$ wide and $4.6 \mathrm{~mm}$ high in the latter. The latter specimen on Plate XII shows a leaf scar situated on slightly raised cushions bearing just a little smaller than the cushion around it. Transitional forms between S. ichtyolepis and typical $S$. brardii are shown on Plate VII, Figs 1, 2, 4, Plate VIII, Figs 1-3, Plate X, Figs 2-4 and Plate XII, Figs 1, 2. These

Plate III. Knorria sp., all specimens come from Planina pod Golico locality; 1) Deeply decorticated stage where nearly all the bark tissues are lost and only parichnos strands are present as longitudinal ridges; specimen No. 44, stored in exposition; scale bar $10 \mathrm{~mm}$; 2) Deeply decorticated stage where nearly all the bark tissues are lost and only parichnos strands are present as longitudinal ridges; specimen stored in exposition scale. 3D cast; bar $20 \mathrm{~mm}$. 


\section{Plate III.}

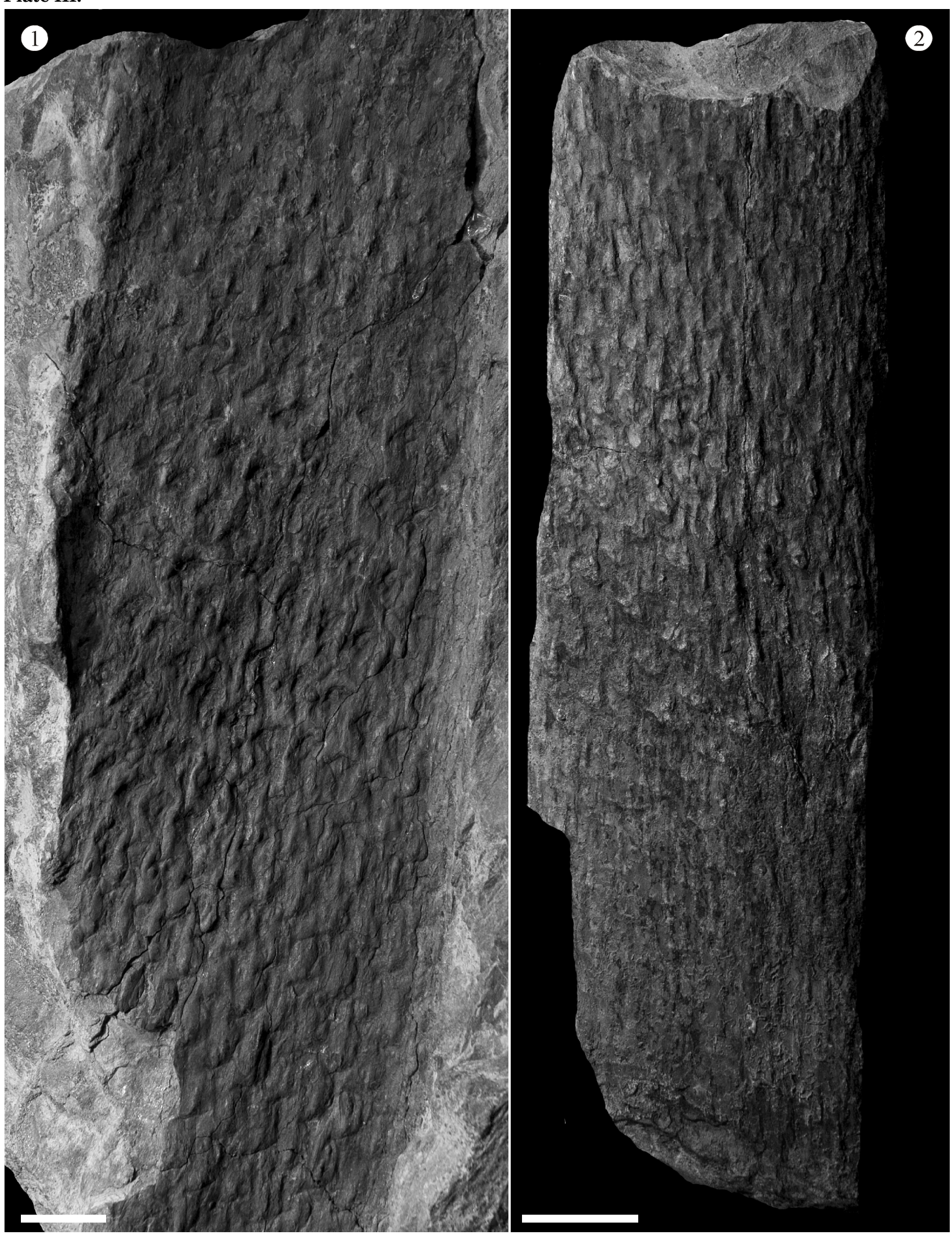



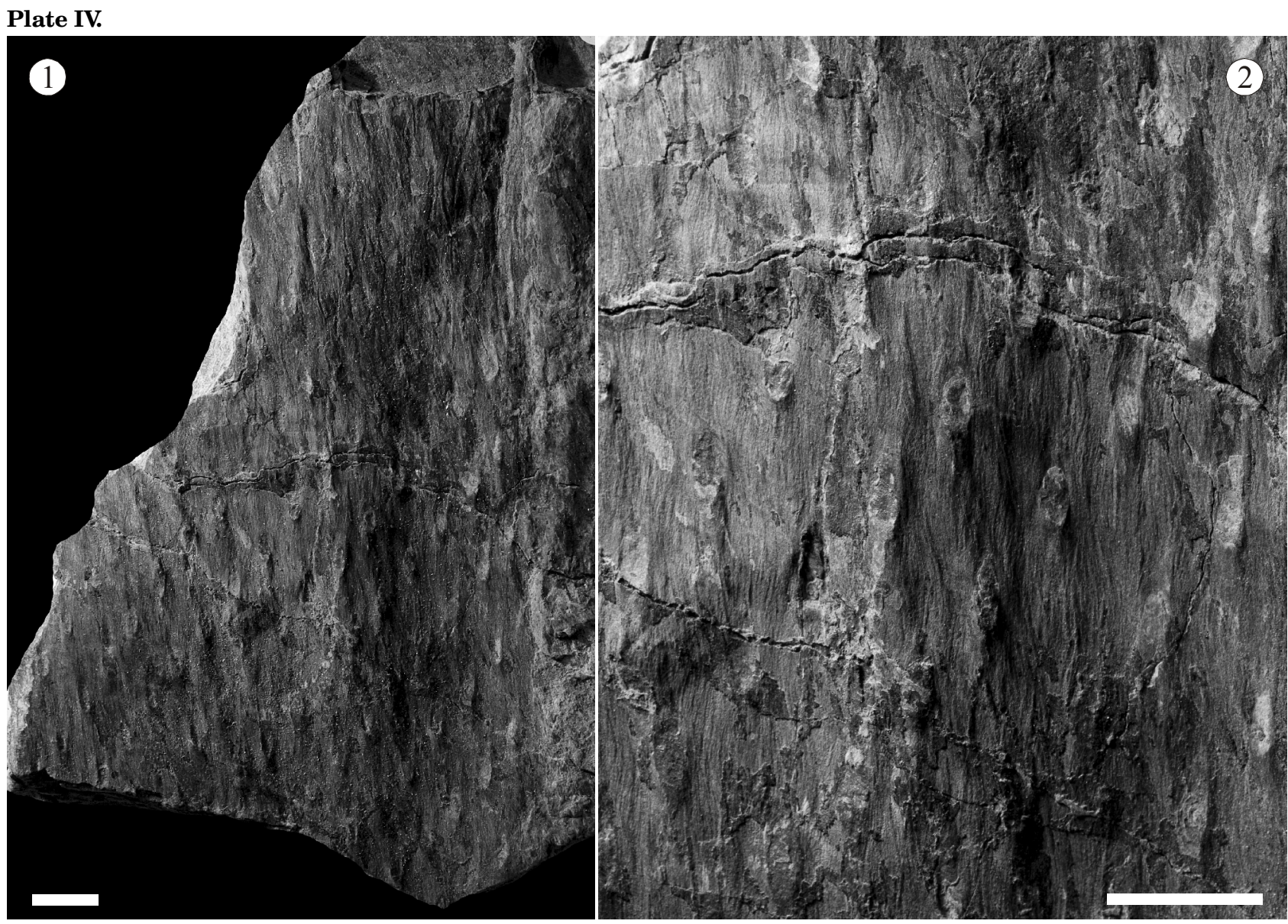

Plate IV. Knorria sp., all specimens come from Planina pod Golico locality; 1) Thick stem with longitudinal ridges. Outline of leaf cushions is not preserved; however, the surface between vertical ridges is covered by vertically to subvertically oriented fine wrinkles; specimen stored in drawer TJ9; scale bar $10 \mathrm{~mm}$; 2) Detail from figure 1; specimen stored in drawer TJ9; scale bar $10 \mathrm{~mm}$.

specimens possess hexagonal leaf scar situated on slightly raised leaf cushion which is much wider than that of the specimen on Plate XII, Fig. 3. The leaf cushion is hexagonal, between $22-24 \mathrm{~mm}$ high and 21 and $23 \mathrm{~mm}$ wide. Leaf scars, which occupy most of the upper half of the cushion, are about $11.5-12.0 \mathrm{~mm}$ wide and $8.5-9.0 \mathrm{~mm}$ high. More or less typical Sigillaria brardii is represented by specimens on Plates VI, Plate VIII, Fig. 4, IX, Figs 1-4, Plate XI, Fig. 1. Leaf scars are situated on flat stem surface either nearly plain or more often with fine subvertical and less commonly horizontal wrinkles. Remaining speci- mens mostly represent various stages of decortication of the stem. Specimen on Plate XII, Fig. 5 preserves grass-like leaves of Cyperites type.

Remarks: Sigillaria brardii is a very common and geographically widespread Stephanian species of the Euramerican province. It has been described nearly from all the basins where strata of this age occur. Its occurrence in Gzhelian strata of the Jesenice area is therefore not surprising. Worth noting is the large variability of this species originally described under different names. For synonymy see Jongmans (1932) and Jongmans and Dijkstra (1969).

Plate V. Sigillaria brardii, all specimens come from Planina pod Golico locality; 1) Specimen shows interlocking disposition and general outline of leaf scars with surrounding fields; scale bar $40 \mathrm{~mm}$; 2) Specimen shows interlocking disposition and general outline of leaf scars with surrounding fields; scale bar $30 \mathrm{~mm}$; 3) Detail from figure 2 shows hexagonal scars which are wider than higher; scale bar $10 \mathrm{~mm}$; 4) Detail from figure 2 shows hexagonal scars which are wider than higher; scale bar $10 \mathrm{~mm}$. 


\section{Plate V.}
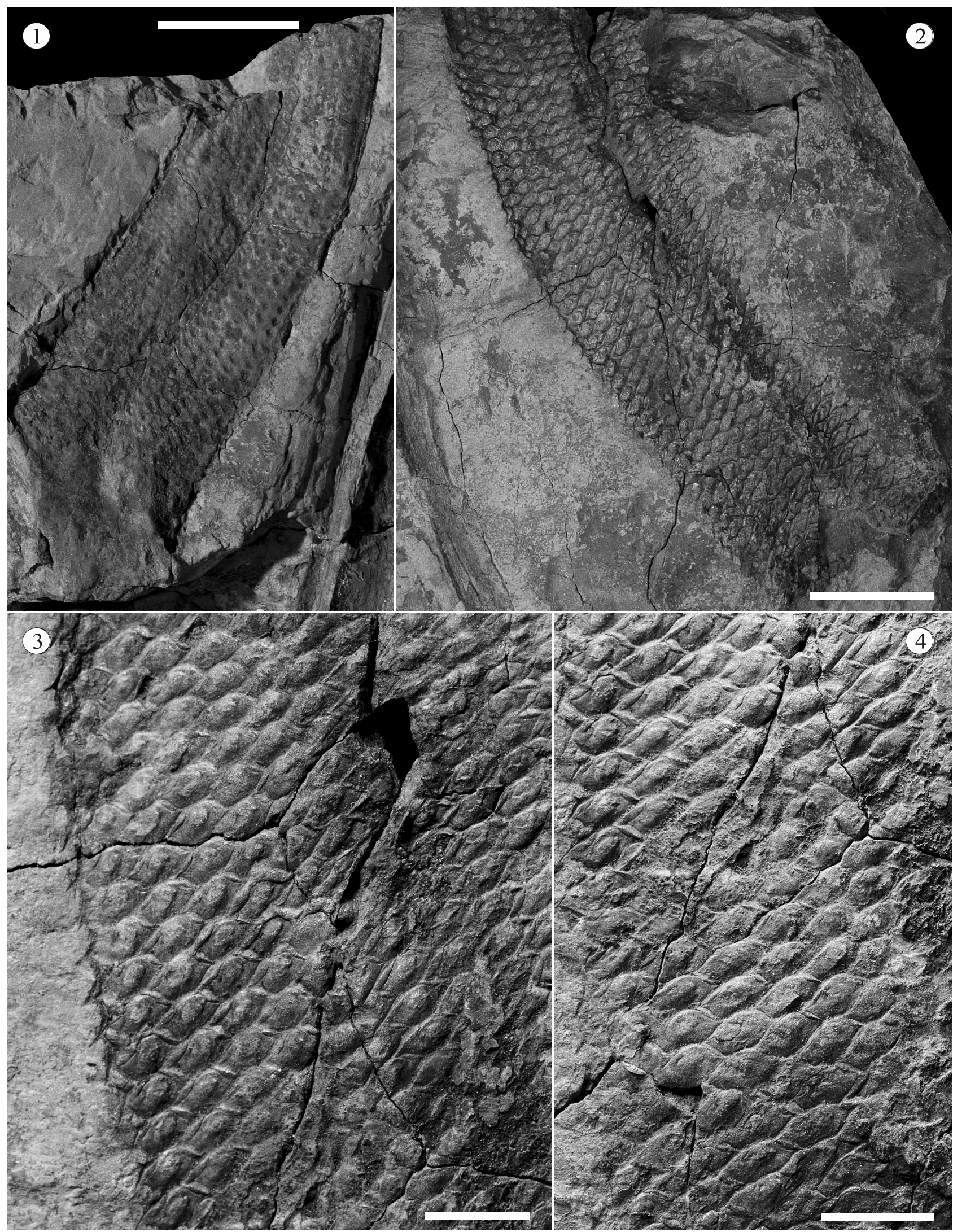


\section{Plate VI.}

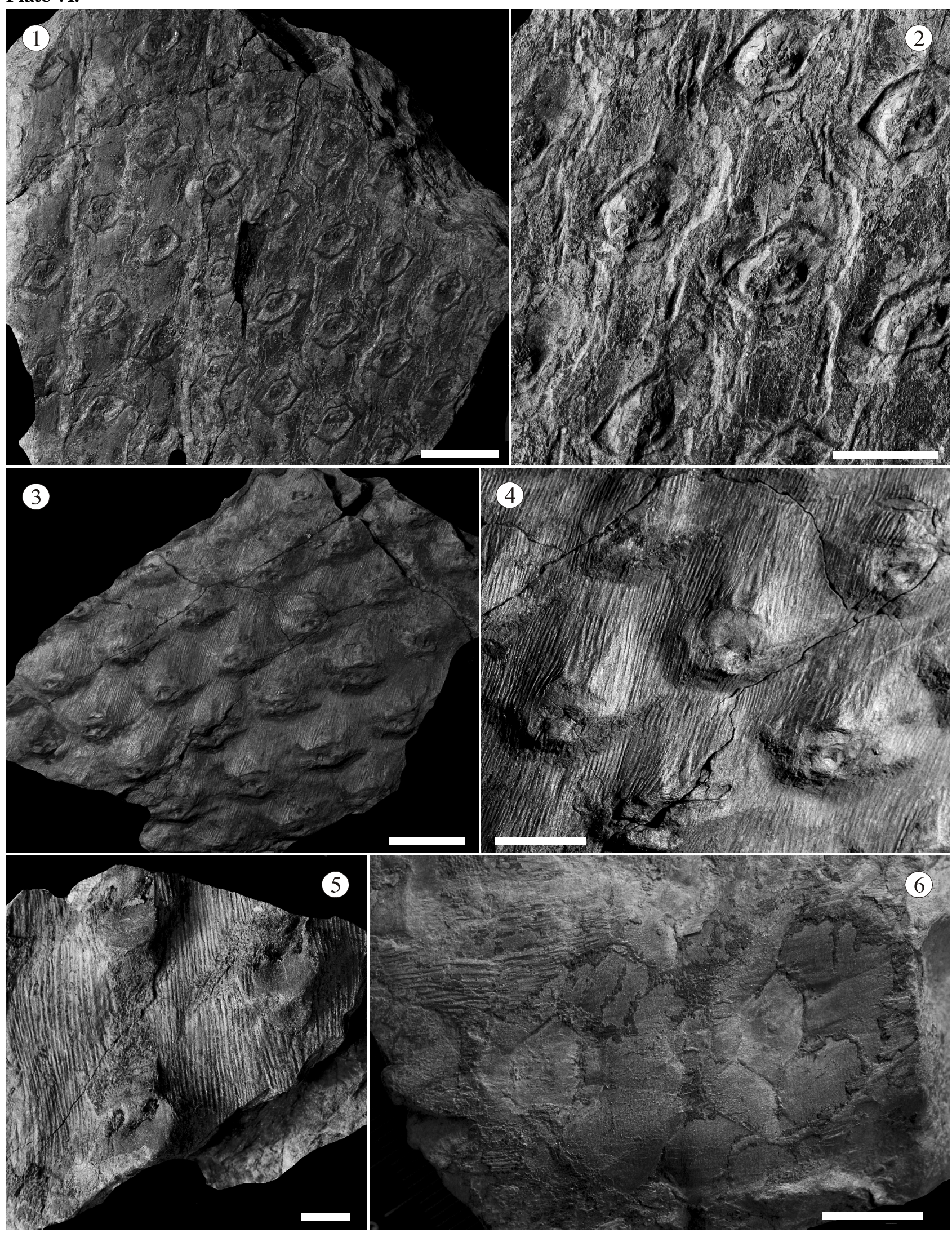




\section{Plate VII.}

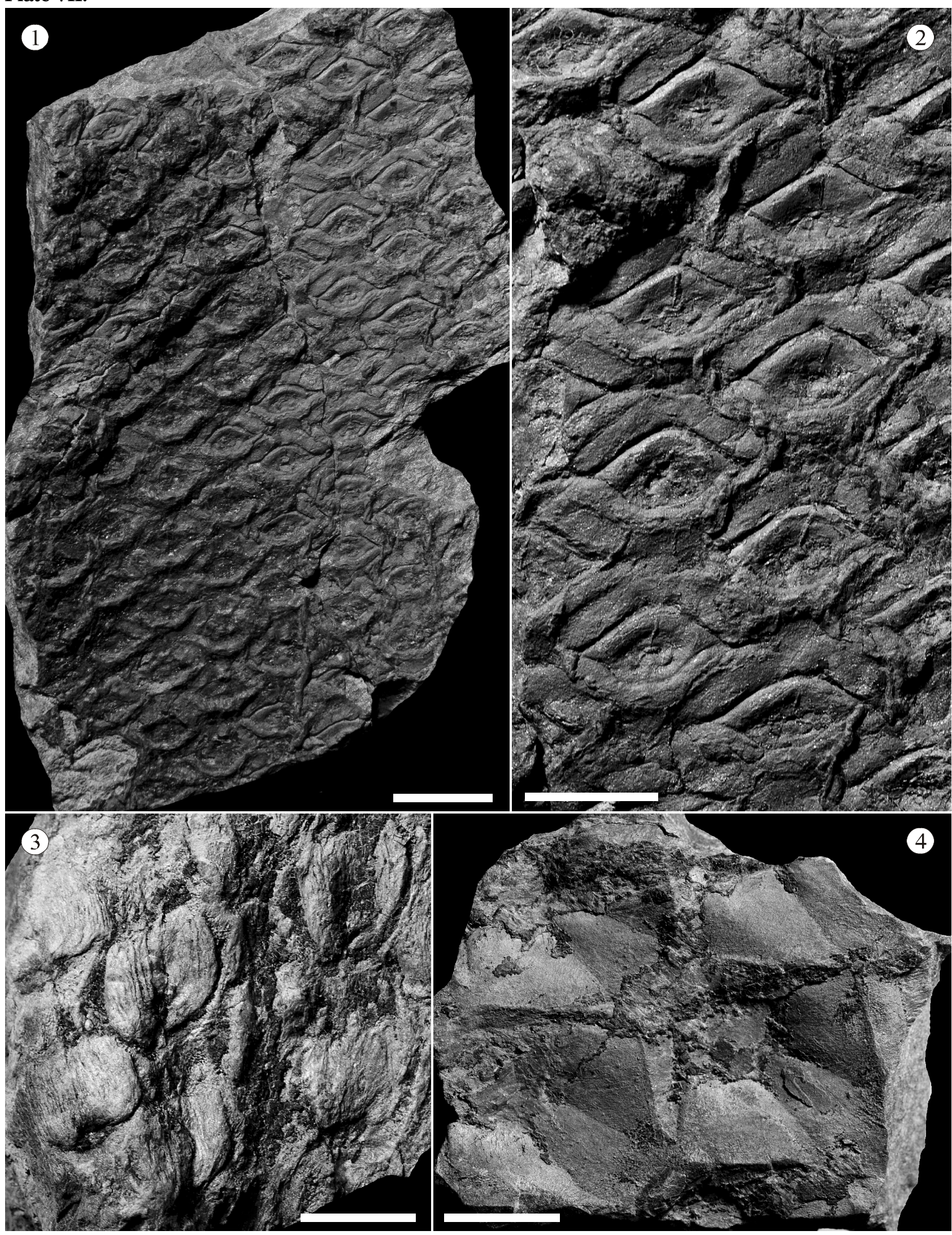




\section{Plate VIII.}

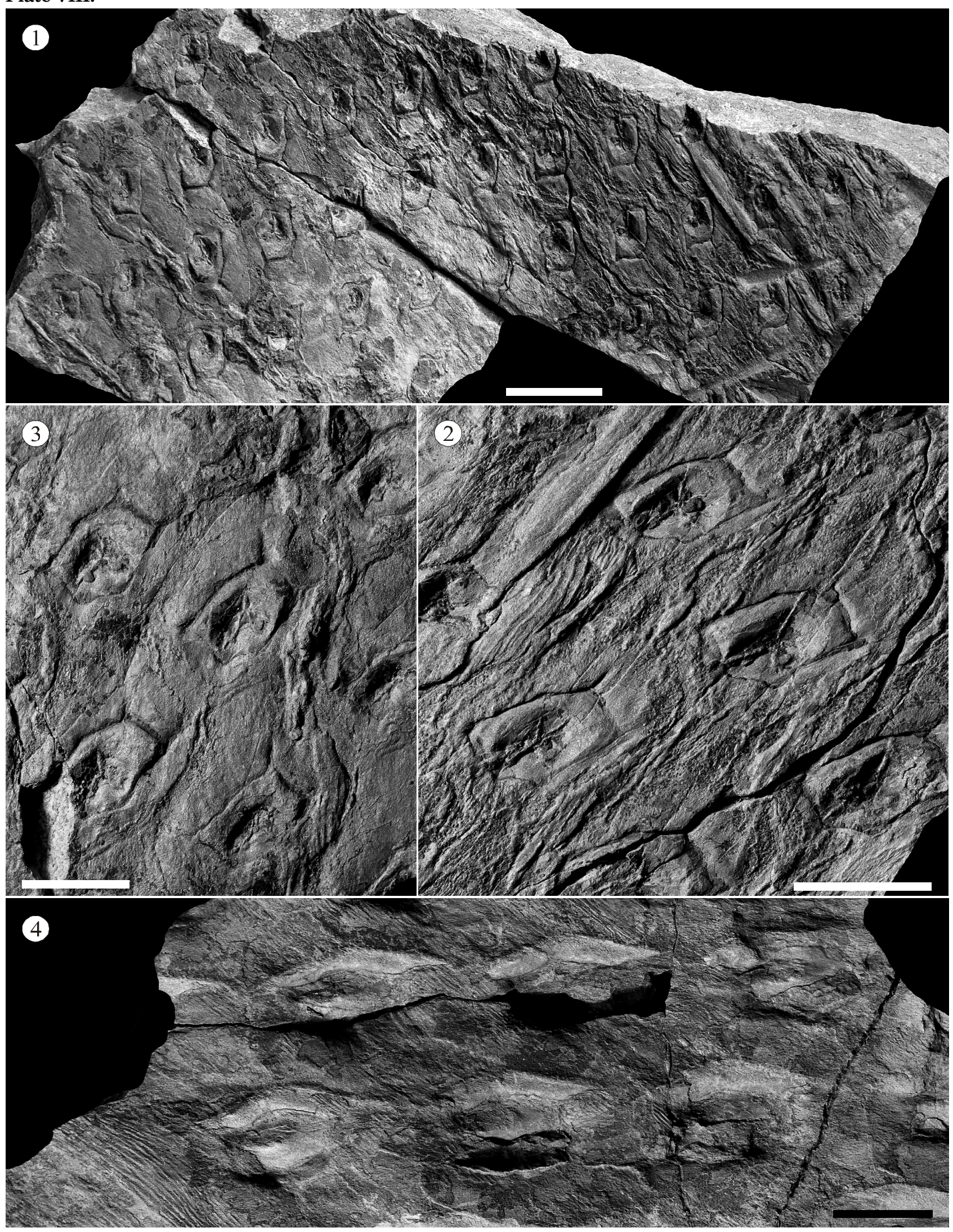




\section{Plate IX.}

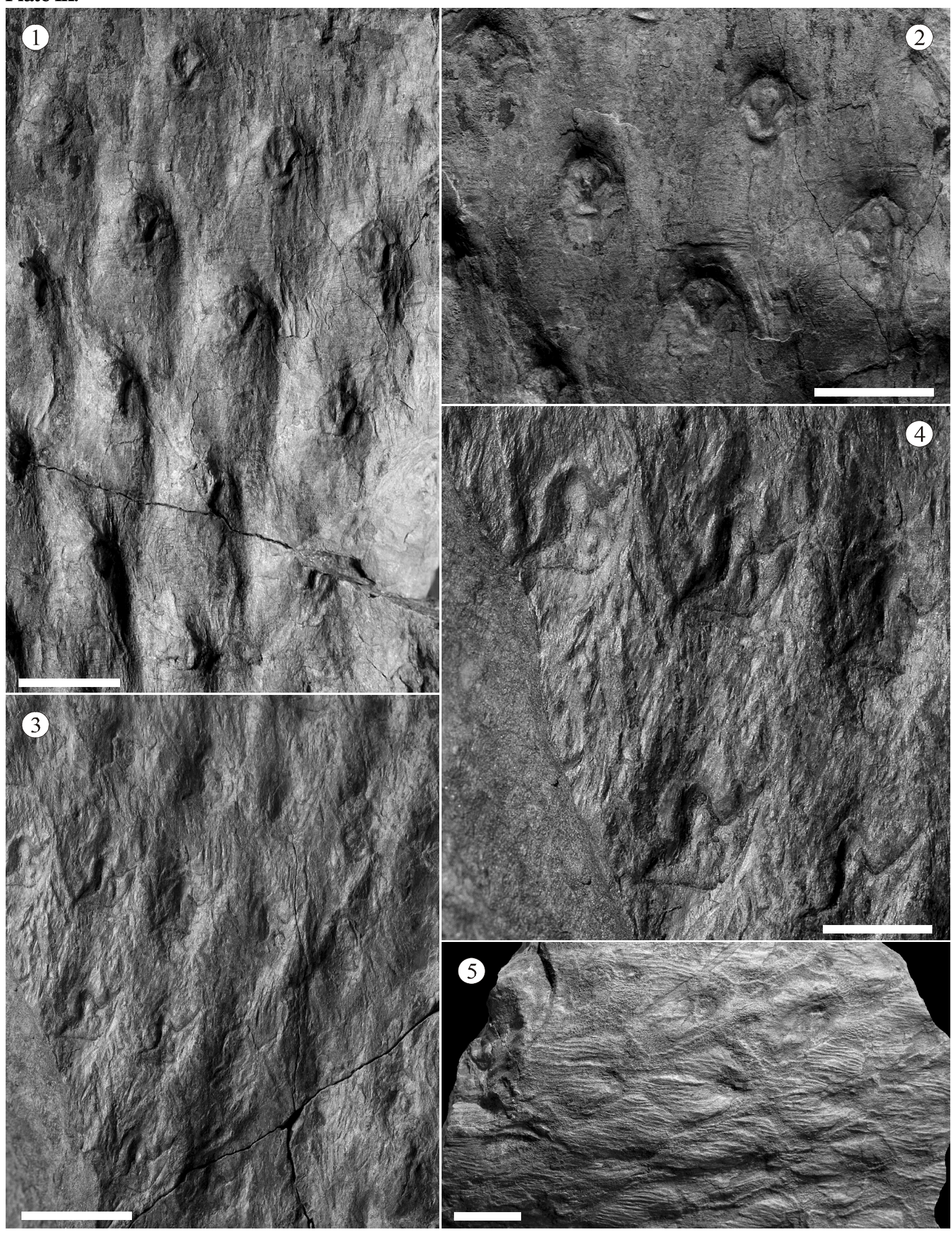




\section{Plate X.}

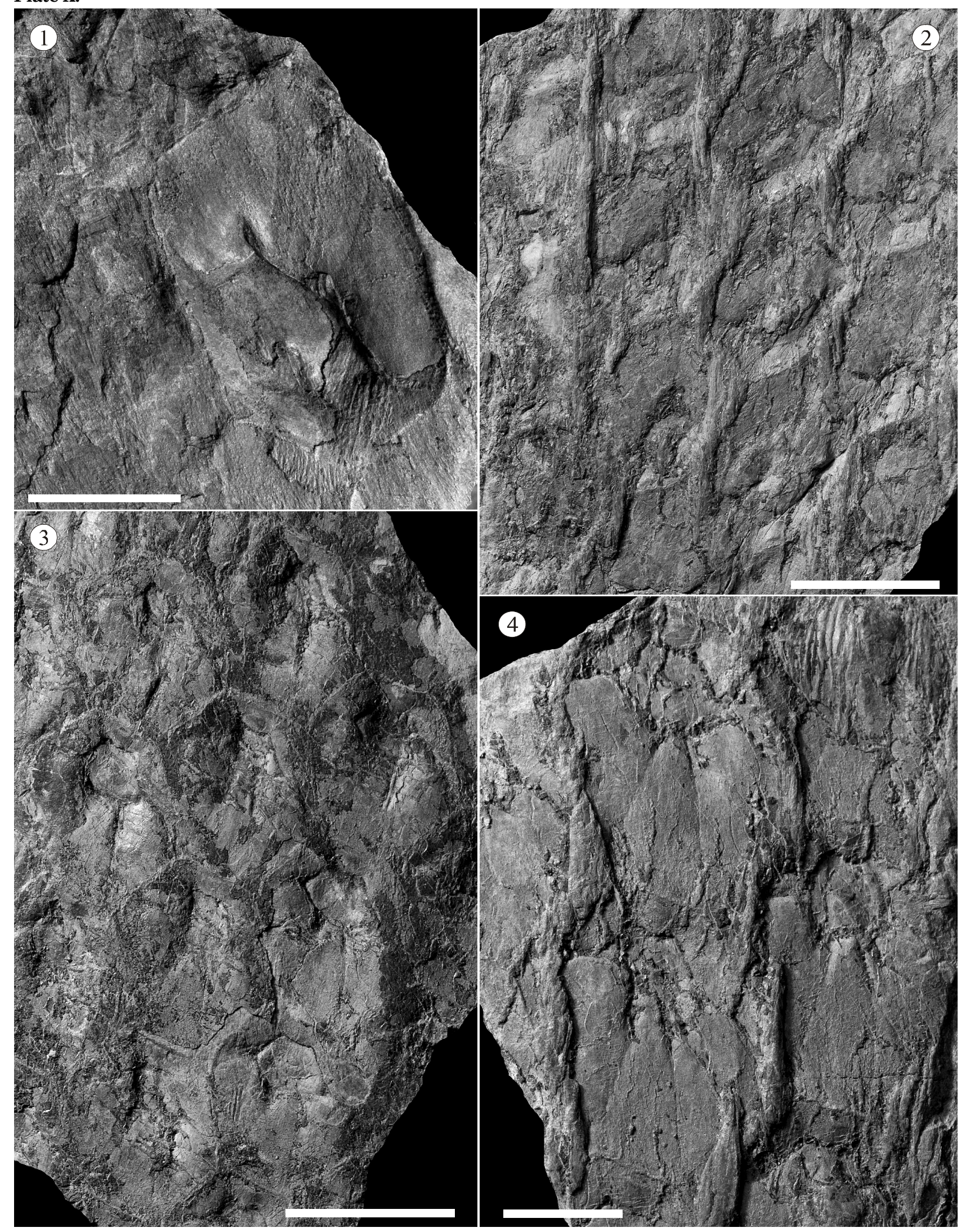




\section{Plate XI.}

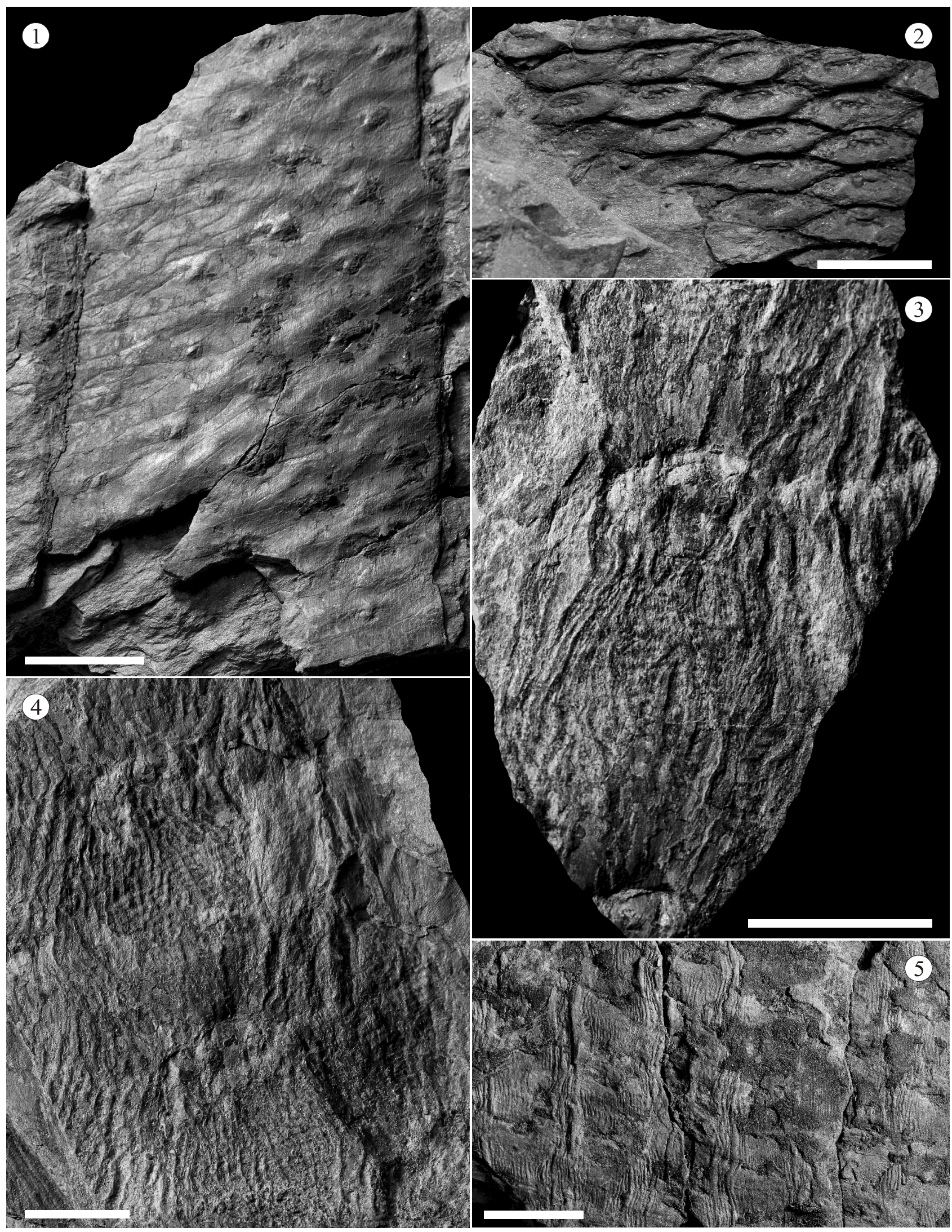


Folia vol. 48, No. 1-2, 2014

\section{Plate XII.}
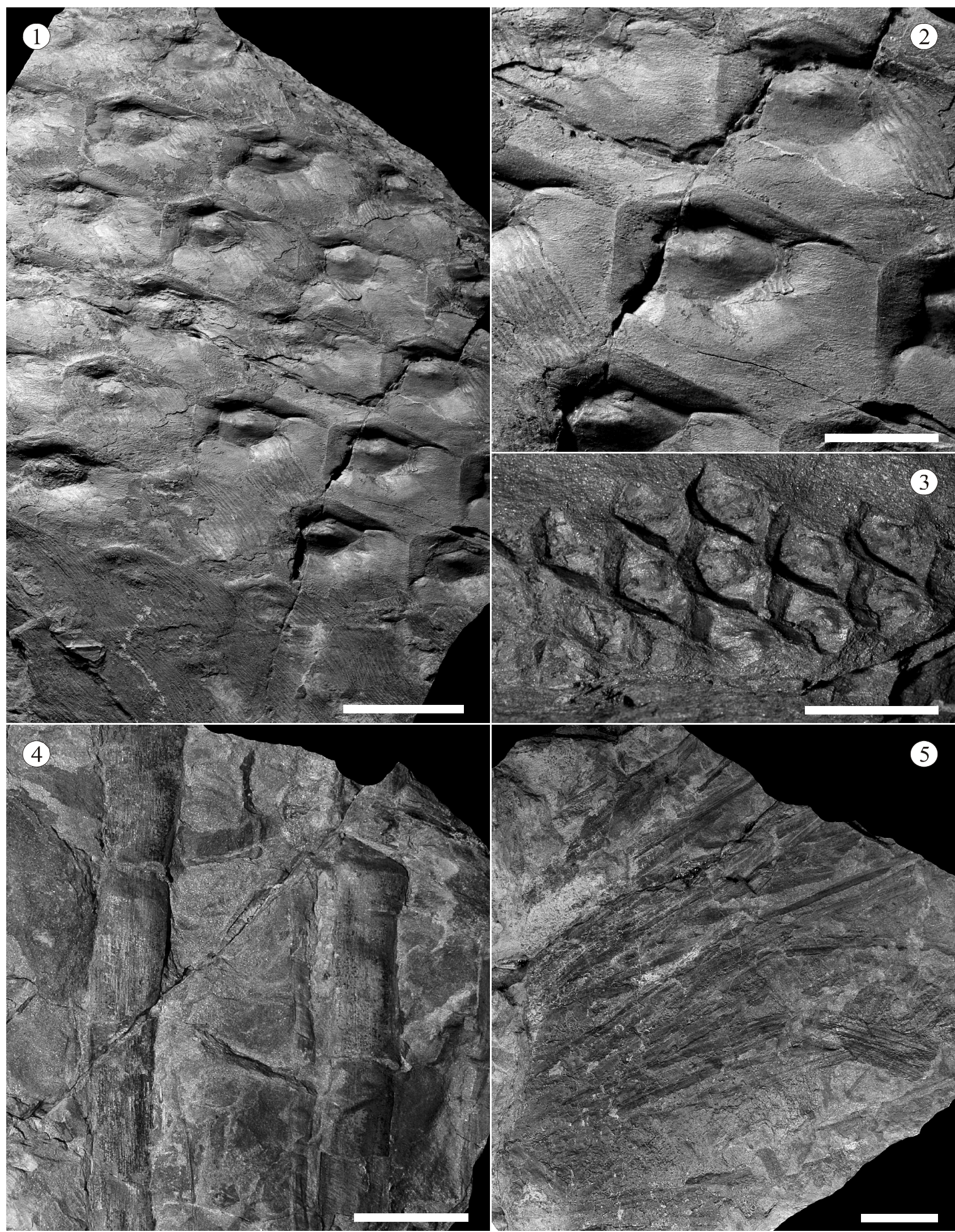
Class Equisetopsida Agardh, 1825

Order Sphenophyllales Seward 1898

Family Sphenophyllaceae Species Sphenophyllum oblongifolium (Germar
and Kaulfuss) Unger (Plate XV)

Sphenophyllum oblongifolium is the only representative of the order Sphenophyllales described from plant assemblage from Planina pod Golico locality. Notwithstand this, these remains are common plant fossils at this locality. Specimens consist of fragments of sterile leafy axes. Axes are from $0.8 \mathrm{~mm}$ (Plate XV, Fig. 3) to $1 \mathrm{~mm}$ (Plate XV, Fig. 1) broad. Leaves are more or less the same type, suggesting that all axes represents the same order (probably twigs) of known branching pattern (Galtier and Daviero, 1999) of the species. The leaves are anisophyllous, trizigioid, varying from $4-10 \mathrm{~mm}$ in length and $2-3 \mathrm{~mm}$ in width (in the broadest part of leaf) (Plate XV, Figs 1 - 3).

Plate VI. Sigillaria brardii, all specimens come from Planina pod Golico locality; 1) Leaf scars are situated on flat stem surface either nearly plain or more often with fine subvertical and less commonly horizontal wrinkles; specimen No. 37, stored in exposition; scale bar $20 \mathrm{~mm}$; 2) Detail from figure 1; specimen No. 37, stored in exposition; scale bar 10 mm. 3) Partly 3D preserved leaf scars which are situated on stem surface either nearly plain or more often with fine subvertical and less commonly horizontal wrinkles; Specimen No. 32, stored in exposition; scale bar $20 \mathrm{~mm}$; 4) Detail from figure 3; specimen No. 32, stored in exposition; scale bar $10 \mathrm{~mm}$; 5) Leaf scars which are situated on stem surface either nearly plain or more often with fine subvertical and less commonly horizontal wrinkles; specimen stored in drawer TJ3; scale bar 5 mm; 6) Leaf scars which are situated on stem surface either nearly plain or more often with fine subvertical and less commonly horizontal wrinkles; specimen stored in drawer TJ3; scale bar $10 \mathrm{~mm}$.

Plate VII. Sigillaria brardii, all specimens come from Planina pod Golico locality; 1) Transition between S. ichtyolepis and typical S. brardii forms; specimen No. 35, stored in exposition; scale bar $20 \mathrm{~mm}$; 2) Detail of leaf scars from figure 1; specimen No. 35, stored in exposition; scale bar $10 \mathrm{~mm}$; 3) Deformed leaf scars; specimen stored in drawer TJ3; scale bar $10 \mathrm{~mm}$; 4) Transition between $S$. ichtyolepis and typical S. brardii forms; specimen stored in drawer TJ3; scale bar $10 \mathrm{~mm}$.

Plate VIII. Sigillaria brardii, all specimens come from Planina pod Golico locality; 1) Specimens possess hexagonal leaf scar situated on slightly raised leaf cushion. The leaf cushion is hexagonal; specimen stored in drawer TJ4; scale bar 20 mm; 2) Detail of leaf scar from figure 1; specimen stored in drawer TJ4; scale bar $10 \mathrm{~mm}$; 3) Detail of leaf scar from figure 1; specimen stored in drawer TJ4; scale bar $10 \mathrm{~mm}$; 4) Leaf scars are situated on flat stem surface either nearly plain or more often with fine subvertical and less commonly horizontal wrinkles; specimen stored in drawer TJ4; scale bar $10 \mathrm{~mm}$.

Plate IX. Sigillaria brardii, all specimens come from Planina pod Golico locality; 1) Leaf scars are situated on flat stem surface either nearly plain or more often with fine subvertical and less commonly horizontal wrinkles; specimen stored in drawer TJ4; scale bar $10 \mathrm{~mm}$; 2) Detail of leaf scars from figure 1; specimen stored in drawer TJ4; scale bar 10 mm; 3) Leaf scars are situated on flat stem surface either nearly plain or more often with fine subvertical and less commonly horizontal wrinkles; specimen stored in drawer TJ4; scale bar $10 \mathrm{~mm}$; 4) Detail of leaf scars from figure 3; specimen stored in drawer TJ4; scale bar $5 \mathrm{~mm}$; 5) Detail of leaf scars; specimen stored in drawer TJ4; scale bar $10 \mathrm{~mm}$.

Plate X. Sigillaria brardii, all specimens come from Planina pod Golico locality; 1) Specimen possesses hexagonal leaf scars situated on slightly raised leaf cushions; specimen stored in drawer TJ4; scale bar $10 \mathrm{~mm}$; 2) Specimen possesses hexagonal leaf scars situated on slightly raised leaf cushions; specimen stored in drawer TJ6; scale bar 20 mm; 3) Specimen possesses hexagonal leaf scars situated on slightly raised leaf cushion; specimen stored in drawer TJ6; scale bar 20 mm; 4) Specimen possesses hexagonal leaf scars situated on slightly raised leaf cushions; specimen stored in drawer TJ6; scale bar $10 \mathrm{~mm}$.

Plate XI. Sigillaria brardii, all specimens come from Planina pod Golico locality; 1) Leaf scars are situated on flat stem surface either nearly plain or more often with fine subvertical and less commonly horizontal wrinkles. Partly decorticated stem; specimen stored in drawer TJ6; scale bar $20 \mathrm{~mm}$; 2) Large leaf scars; specimen No. 41; specimen stored in drawer TJ8; scale bar $10 \mathrm{~mm}$; 3) Specimen shows a detail of leaf cushion; specimen stored in drawer TJ9; scale bar $10 \mathrm{~mm}$; 4 ) Specimen shows a detail of leaf cushion; specimen stored in drawer TJ8; scale bar $10 \mathrm{~mm}$; 5) Leaf scars are situated on flat stem surface either nearly plain or more often with fine subvertical and less commonly horizontal wrinkles; specimen stored in drawer TJ9; scale bar $20 \mathrm{~mm}$.

Plate XII. Sigillaria brardii, all specimens come from Planina pod Golico locality; 1) Specimen possesses hexagonal leaf scars situated on slightly raised leaf cushions; specimen stored in drawer TJ9; scale bar 20 mm; 2) Specimen possesses hexagonal leaf scars situated on slightly raised leaf cushions; specimen stored in drawer TJ9; scale bar $10 \mathrm{~mm}$; 3) Detail of large leaf scars; specimen No. 34; specimen stored in drawer TJ10; scale bar $10 \mathrm{~mm}$; 4) Specimens shows probably 3d preserved appendices from lycopsid root system; scale bar $20 \mathrm{~mm}$; 5) Specimen shows grass-like leaves of Cyperites type; scale bar $20 \mathrm{~mm}$. 
The venation is not well visible but one vein enters each leaf base, afterwards dichotomizing at last three times. The internodes varied from $3 \mathrm{~mm}$ to $10 \mathrm{~mm}$ depending on the size of leaves.

Remarks: This is a well know cosmopolitan species (e.g. Lee, 1963; Boureau, 1964; Zodrow, 1989; Galtier and Daviero, 1999), which is know from several Carboniferous/Permian basins of Europe, Canada, USA, Korea or China. This species is widely known from Stephanian into Lower Permian, nevertheless some author mentioned rare occurrence of this species in Asturian (Boureau, 1964; Zodrow, 1989).

Order Equisetales Dumortier, 1829

Family Calamostachyaceae

Species Calamites (Stylocalamites) undulatus Sternberg (Plate XIII, Figs 1, 2)

Several specimens were found at the Planina pod Golico locality. The surface of the specimens are almost smooth with very fine longitudinal and slightly flexuous canals. The canals are $1.5 \mathrm{~mm}$ wide. The internodes are generally less elongated than broad (Plate XIII, Fig. 1), sometimes longer than wide (Plate XIII, Fig. 2). The internodes vary from 20 to $150 \mathrm{~mm}$. The leaf scars are poorly visible in the specimen figured on Plate XIII, Fig. 1 (L). They are $1 \mathrm{~mm}$ in diameter, slightly elongated and elliptic in shape. The branch scars vary from 7 to $13 \mathrm{~mm}$ in diameter [Plate XIII, Figs 1 (B), 2 (arrow)]. They are oval or slightly elliptic with longer axe parallel with the node zone. The branch scars are situated on the nodes. Only one branch scar is placed on one node and branch scars are not at all nodes.
Species Calamites sp. (Plate XIII, Figs 3-5)

Several narrower shoots of calamitalean species are present at the Planina pod Golico locality. The specimens show shoots which varied from $13 \mathrm{~mm}$ (Plate XIII, Fig. 3) to $35 \mathrm{~mm}$ in width (Plate XIII, Figs 4, 5). Nevertheless, the canals are $1.5 \mathrm{~mm}$ wide in all specimens. The internodes are longer than wide (Plate XIII, Fig. 4). Leaf and branch scars are not present/visible on these specimens.

Remark: Based on the fact that we have only of large stems of Calamites undulatus, we can assume that this narrower shoot represents the branches of this species.

\section{Species Annularia carinata Gutbier (Plate XIV)}

This type of calamitalean leaf is really common on both studied localities. In some large specimens, three remains of several leaf whorls (Plate XIV, Figs 1, 3). Each whorl bears about 20 leaves. The axis is $1.5-3 \mathrm{~mm}$ broad. Two adjacent whorls are spaced $15-30 \mathrm{~mm}$. The leaves are anisophyllous and broadest in their distal third. Due to anisophyll character the length of leaves varied from $9 \mathrm{~mm}$ to $33 \mathrm{~mm}$ with their width $2-3 \mathrm{~mm}$ in their broadest part. The all leaves have typically mucronate tips (Plate XIV, Fig. 7).

Remark: The remains of this species show great variability, especially in the size of leaves. The really small leaves are figured on Plate XIV, Fig. 8 while large leaves are figured on Plate XIV, Fig. 6. This specimen (Plate XIV, Fig. 6) may resemble Annularia spinulosa Sternberg, nevertheless, the tip of leaf is mucronate (Plate XIV, Fig. 7), while leaves of true Annularia spinulosa have long spiny tips (Barthel, 2000). Based on the fact that only one calamitalean cone is known from both localities, we assumed that all specimens (Plate XIV) represent leaf variability of one natural species.

Plate XIII. All specimens come from Planina pod Golico locality; 1) Calamites (Stylocalamites) undulatus; specimen shows stem with poorly visible leaf scars (L) and larger branch scares (B); specimen stored in drawer TJ7; scale bar 20 mm; 2) Calamites (Stylocalamites) undulatus; specimen shows stem with fine longitudinal and slightly flexuous canals. Arrow indicates the branch scar; specimen No. 48; specimen stored in drawer TJ7; scale bar 20 mm; 3) Calamites sp., specimen shows narrower shoots of calamitalean species without nodes; specimen stored in drawer TJ7; scale bar 10 mm; 4) Calamites sp., specimen shows narrower shoot of calamitalean species with node; specimen stored in drawer TJ7; scale bar 10 mm; 5) Calamites sp., Specimen shows partly deformed shoot of calamitalean species; specimen stored in drawer TJ7; scale bar $10 \mathrm{~mm}$; 6) Calamostachys cf. germanica; specimen represents clearly articulated cone with perpendicular bracts attached in nodes; specimen stored in drawer TJ1; scale bar $10 \mathrm{~mm}$. 


\section{Plate XIII.}

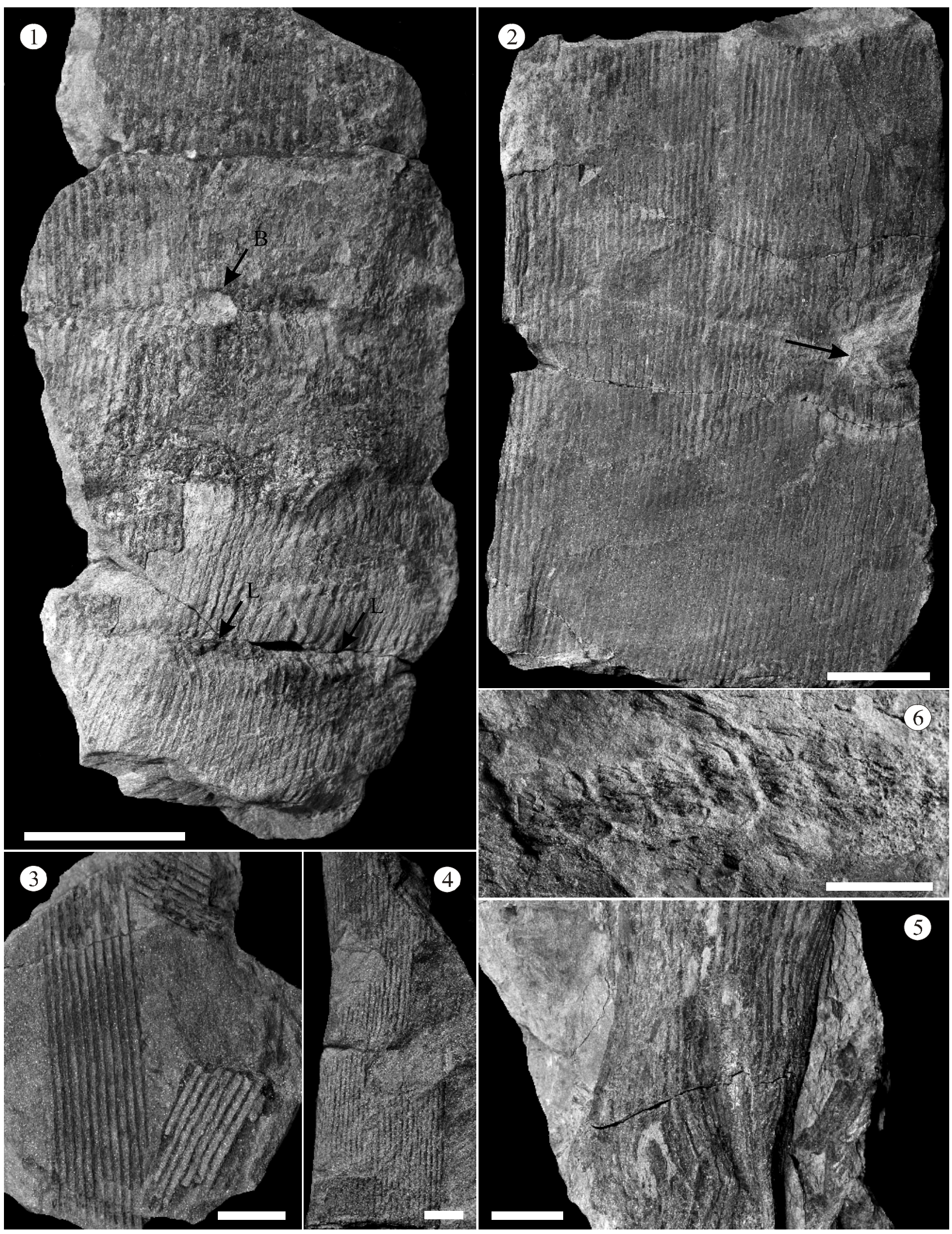


Folia vol. 48, No. 1-2, 2014

\section{Plate XIV.}

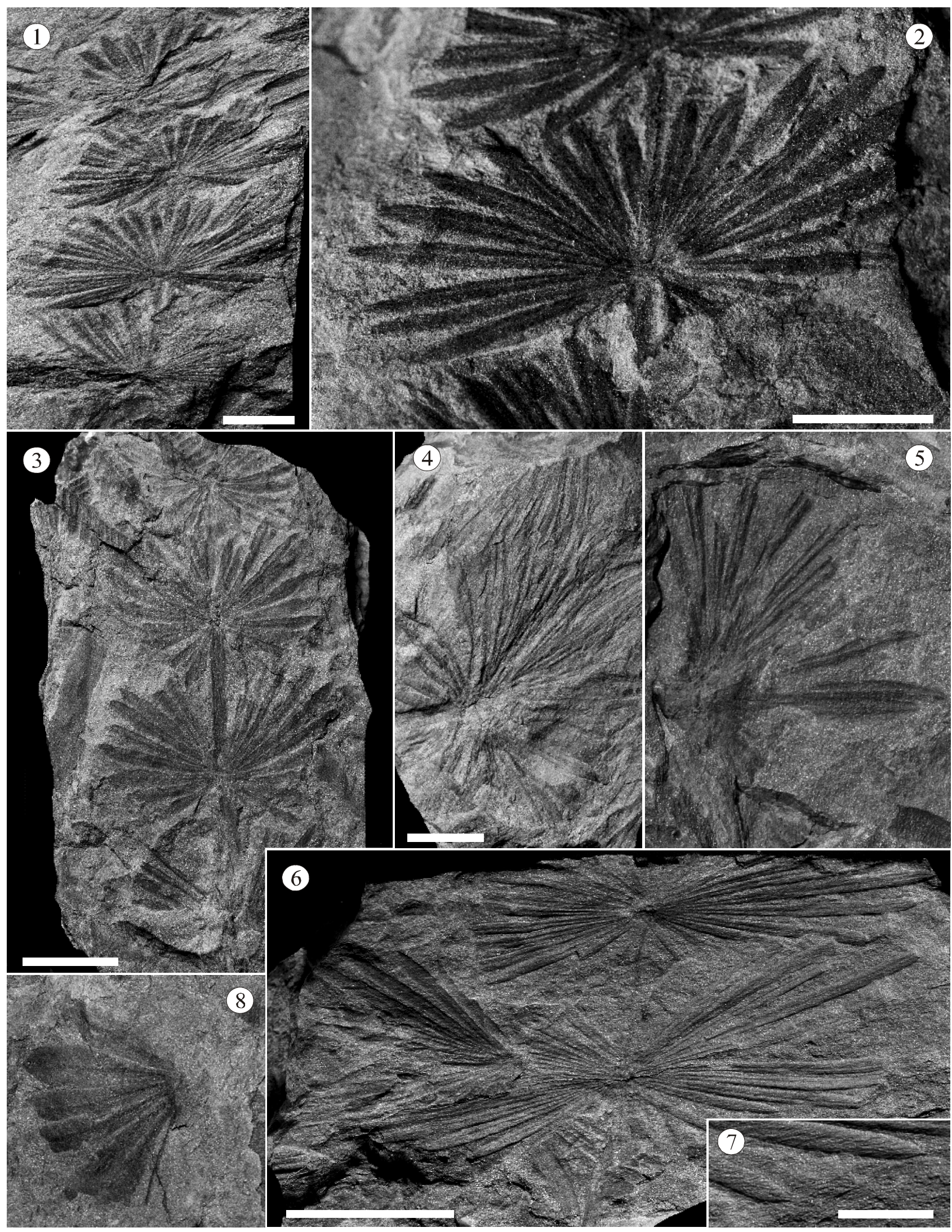



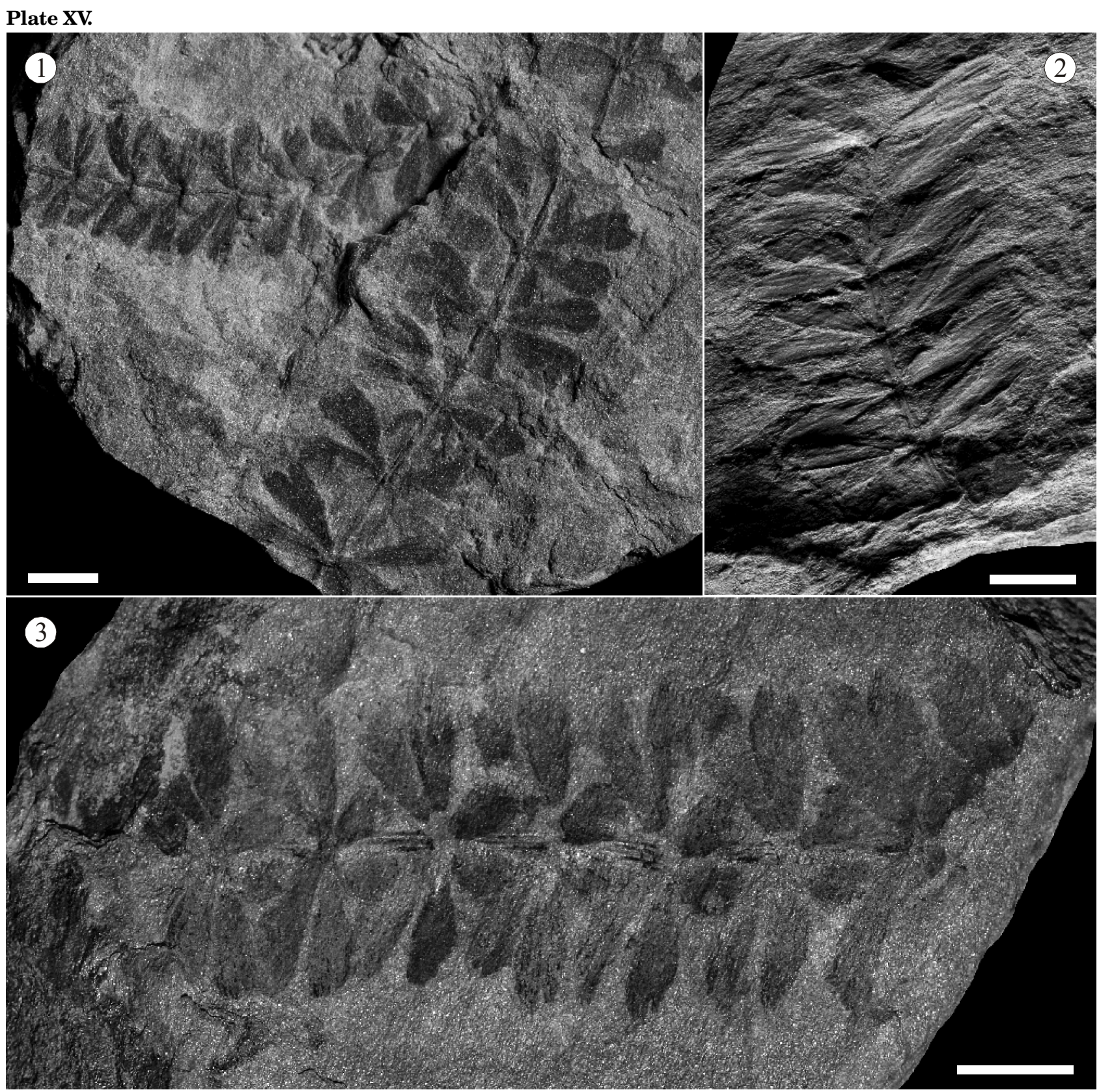

Plate XV. Sphenophyllum oblongifolium, all specimens come from Planina pod Golico locality; 1) Specimen shows two fragments of sterile leafy axes with anisophyllous, trizigioid leaves; scale bar $5 \mathrm{~mm}$; 2) Specimen shows a fragment of sterile leafy axis with anisophyllous, narrow, trizigioid leaves; specimen stored in drawer TJ; scale bar 5 mm; 3) Specimen shows a fragment of sterile leafy axis with are anisophyllous, trizigioid leaves; specimen stored in drawer TJ9; scale bar 5 mm.

Plate XIV. Annularia carinata, figures 1-4, 6 and 7 come from Planina pod Golico locality, figures 5 and 8 come from Javorniški Rovt locality; 1) Specimen shows several leaf whorls with anisophyllous leaves; specimen No. 24; scale bar 10 mm; 2) Detail of anisophyllous leafs from figure 1; specimen No. 24; scale bar $10 \mathrm{~mm}$; 3) Specimen shows several leaf whorls with anisophyllous leaves; scale bar $20 \mathrm{~mm}$; 4) Detail of anisophyllous leafs; specimen stored in drawer TJ9; scale bar $10 \mathrm{~mm}$; 5) Detail of anisophyllous leaves; specimen stored in drawer TJ2; scale bar $10 \mathrm{~mm}$; 6) Specimen shows several leaf whorls with long anisophyllous leaves; specimen No. 27; specimen stored in drawer TJ9; scale bar $20 \mathrm{~mm}$; 7) Detail of mucronate tip of leaves from figure 6; specimen No. 27; specimen stored in drawer TJ9; scale bar $5 \mathrm{~mm}$; 8) Specimen shows small leaves each with mucronate tip; specimen stored in drawer TJ9; scale bar $5 \mathrm{~mm}$ 
Species Calamostachys $\mathrm{cf}$. germanica (Plate XIII, Fig. 6)

We found only one specimen of this species from the collection from both localities. However the specimen is poorly preserved. It represents a clearly articulated cone more than $40 \mathrm{~mm}$ long and $8 \mathrm{~mm}$ wide in its broadest part (including the bracts). The axis is not well visible, $2 \mathrm{~mm}$ broad. Bracts are perpendicular, attached in nodes. The number of bracts per whorl are unknown, but they are $4 \mathrm{~mm}$ long, linear-lanceolate. The distance between two neighboring whorls of sterile bracts measures $3.5 \mathrm{~mm}$. The sporangia are not well visible but they appear to be attached to a sporangiophore which is perpendicularly attached to the cone axis in the lower part of the internodes. The number of sporangia per sporangiophore is unknown due to poor preservation.

Remarks: The specimens could be compared with Calamostachys germanica Weiss (Němejc 1953) based on the fact that both are more or less similar in length, the axes are $2-2.5 \mathrm{~mm}$ broad, the distance between two neighboring whorls of sterile bracts of both species measure $3.5 \mathrm{~mm}$, and sporangiophores are attached to the axis in the lower part of the internode. Bracts are linear-lanceolate in both species. Nevertheless, a detailed comparison of the sporangia could not be made because the Slovenian cone is so poorly preserved.

Order Zygopteridales sensu Taylor and Taylor, 1193 Family Zygopteridaceae

Species Nemejcopteris feminaeformis (Schlotheim) Barthel (Plate XVI)

Large parts of this species are known from both studied localities. All specimens represent sterile pinnules only. Several specimens show a large part of a penultimate pinna with several incomplete ultimate pinnae (Plate XVI, Fig 1). The penultimate rachis is $4 \mathrm{~mm}$ broad, and was originally spiny as indicated by rounded marks on the surface (Plate
XVI, Fig. 1 arrow). Ultimate pinnae are elongated with parallel sides, more than $80 \mathrm{~mm}$ long. The ultimate rachis is $1 \mathrm{~mm}$ broad. Pinnules alternated on the ultimate rachis, to which they are attached at under $80^{\circ}$. Pinnules are probably rigid, connate with each other at their bases, with a serrated margin. They are $8-10 \mathrm{~mm}$ long and $3 \mathrm{~mm}$ wide. A midvein is marked along $1 / 3-1 / 2$ the pinnule length. Lateral veins are simple, strong, and form an angle of $20-25^{\circ}$ with the midvein.

Remarks: The specimens from the studied locality are identical with the material published by Barthel (1968). Bather (1968) mentioned that this species was a scrambling/climbing type plant. Based on this fact, and the fact that the remains of it are really common, we can assume that the species was a significant part of the understory. Unfortunately, fertile specimens have not been discovered.

Class Marattiopsida Doweld, 2001

Order Marattiales Link, 1833

Family Asterothecaceae

Species Acitheca polymorpha (Brongniart) Schimper (Plates XVII - XIX)

Remains of this species are really common in both studied localities. Large parts of sterile penultimate pinnae and some sterile ultimate pinnae occur in both localities. The material provides clear evidence of the variation in the pinnule morphology within the frond. The penultimate pinnae are large in size. The margins of penultimate pinna form an angle $85^{\circ}$ in apical part of the pinna (Plate XVII, Fig. 2). The penultimate rachis is not well visible in all specimens but they are $1.8-2 \mathrm{~mm}$ broad. Ultimate pinnae are alternately arranged on the penultimate rachis, inserted at about $70^{\circ}$. Most ultimate and penultimate rachises appear rigid and straight. The ultimate pinnae are parallelsided for most of their length (Plate XVII, Fig. 3, Plate XVIII, Figs 3,4) tapering only in their very

Plate XVI. Nemejcopteris feminaeformis, figure 1 comes from Javorniški Rovt locality and figure 2 comes from Planina pod Golico locality; 1) Large part of penultimate pinna with several incomplete ultimate pinnae; specimen No. 23; specimen stored in drawer TJ2; scale bar $20 \mathrm{~mm}$; 2) Detail of ultimate pinnae with rigid, connate pinnules with serrated margin; specimen stored in drawer TJ1; scale bar $5 \mathrm{~mm}$. 


\section{Plate XVI.}

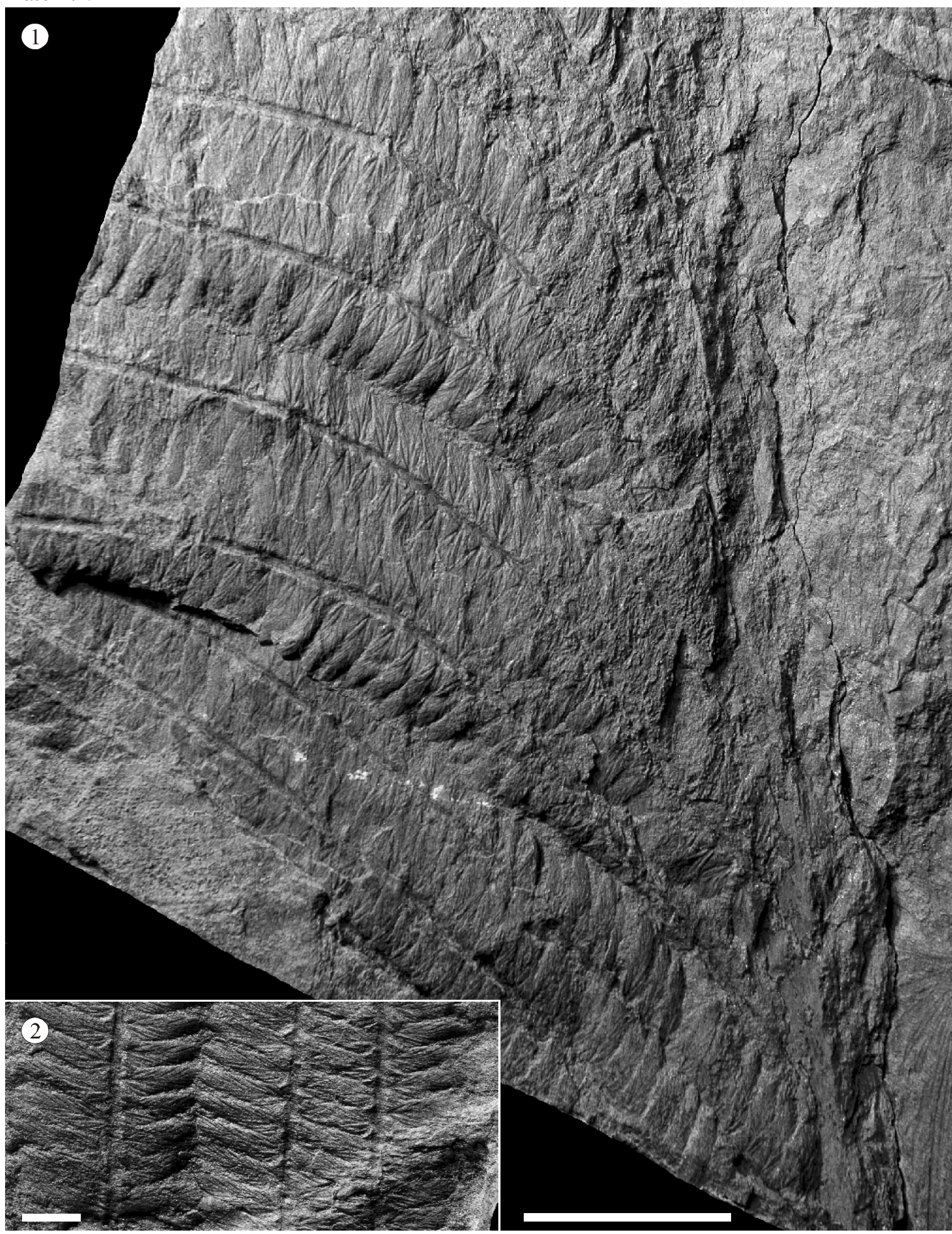


distal part to form an obtuse apex (Plate XVIII, Figs 2,4$)$. The pinnae are terminated by a small apical pinnule which is differentiated from the adjacent lateral pinnules (Plate XVII Fig. 4 arrow, Plate XVIII, Fig. 4 arrow). The ultimate pinnae are often asymmetrical about the rachis, with basiscopic pinnules being more elongate and a little more oblique than the acroscopic pinnules (Plate XVIII, Fig. 3). The pinnules also become a little more oblique towards the pinna apex (Plate XVIII, Fig. 1, Plate XIX, Fig. 5), but typically they are linguaeform with a round (Plate XVIII, Fig. 3), obtuse or somewhat tapered apex, and a partly constricted base. The smallest pinnules are $4 \mathrm{~mm}$ long and $2 \mathrm{~mm}$ wide, ovate or subtriangular (Plate XVIII, Fig. 1), while the larger pinnules become pinnatifid, $5-10 \mathrm{~mm}$ long and $2.5-3 \mathrm{~mm}$ wide (Plate XVIII, Figs 2, 4). Pinnule length/breadth ratio varies from 2 in the smallest to 4 in the largest pinnules. Most commonly ratio is about 3 . The pinnules are mostly closely spaced. The midvein is straight (Plate XVIII, Fig. 3) and lies in a shallow furrow. The midvein extends for $>90 \%$ of the pinnule length. The lateral veins start at an acute angle to the midvein, arch relatively sharply and meet the pinnule margin typically at $80-90^{\circ}$ ( $70^{\circ}$ in the largest pinnules) (Plate XVIII, Fig. 3). The lateral veins fork once or twice, with the first dichotomy occurring near the midvein (polymorphopterid-veining pattern sensu Wagner, 1958).

Fertile pinnules are similar in shape to the sterile ones (Plate XIX, Fig. 2). Nevertheless, some fertile pinnules appear to be narrower due to taphonomic folding along the midvein (Plate XIX, Fig. 3). The pinnules typically have 16 - 20 synangia in two rows, one on either side of the midvein. The synangia normally obscure the lateral veins. The margins of fertile pinnules curve downward and partly hide the proximal part of the synangia, with the distal part protruding beyond the pinnule margin. Usually, sporangia are covered by the pinnule lamina. Sporangia are not well preserved and so details of the sporangial character could not be determined. Synangia are $2-3 \mathrm{~mm}$ long.
Species Pecopteris victoriae Corsin (Plate XX, Figs 1, 2)

This species is rare and it is represented by small fragments of sterile or fertile ultimate pinnae. Sterile ultimate pinnae are $30 \mathrm{~mm}$ wide and more than $60 \mathrm{~mm}$ long. The ultimate rachis is haired, $1.2 \mathrm{~mm}$ broad. Pinnules alternately arranged on the ultimate rachis and inserted at about $50^{\circ}$. They are $15-18 \mathrm{~mm}$ long and $3 \mathrm{~mm}$ wide. The apex of pinnules are subtriangular, obtuse, somewhat tapered to the apex (Plate XX, Fig. 1). The margin of the pinnules is parallel, straight or very slightly lobate. The pinnules are mostly closely spaced and slightly adherent to each other at the base. The pinnules of fertile specimens appear not closely spaced but in reality this is a taphonomic effect, with pinnules being folded along the midvein (Plate XX, Fig. 2). The venation is visible only on sterile pinnules and then not clearly (Plate XX, Fig. 1). The midvein is straight, extends for $4 / 5$ of the pinnule length. The lateral veins start at an acute angle to the midvein, arch relatively sharply and meet the pinnule margin. The lateral veins fork once, where the first dichotomy is near the midvein.

Detail about the synangia/sporangia cannot be seen because the specimens are poorly preserved.

Remarks: Pinnules of this species described in this paper are little longer $(15-18 \mathrm{~mm})$ in comparison with Corsin (1956, p. 247) description (10 - $16 \mathrm{~mm})$. Nevertheless, the length of pinnules of the same species could be due to ecological inter-species variability.

Description of the specimens partly compare with Acitheca polymorpha (Zodrow et al., 2006) but differ mainly in the type of venation. Acitheca polymorpha has lateral veins starting at an acute angle to the midvein, arch relatively sharply, meet the pinnule margin typically at $80-90^{\circ}$, and fork once or twice with the first dichotomy near the midvein. Pecopteris victoriae, in contrast, has lateral veins that start at an acute angle to the midvein, arch relatively sharply and meet the pinnule margin and fork once only with the first dichotomy near the midvein.

Plate XVII. Acitheca polymorpha, all specimens come from Planina pod Golico locality; 1) Specimen shows part of sterile penultimate pinnae; specimen No. 4; specimen stored in exhibition; scale bar $20 \mathrm{~mm}$; 2) Apical part of sterile penultimate pinnae; specimen No. 6; scale bar $20 \mathrm{~mm}$; 3) The middle part of sterile penultimate pinnae with typically linguaeform pinnules; specimen No. 8; scale bar $10 \mathrm{~mm}$. 


\section{J. Pšenička, T. Kolar-Jurkovšek, S. Opluštil \& M. Novak, Stephanian fossil flora from Paralic Carboniferous deposits}

\section{Plate XVII.}
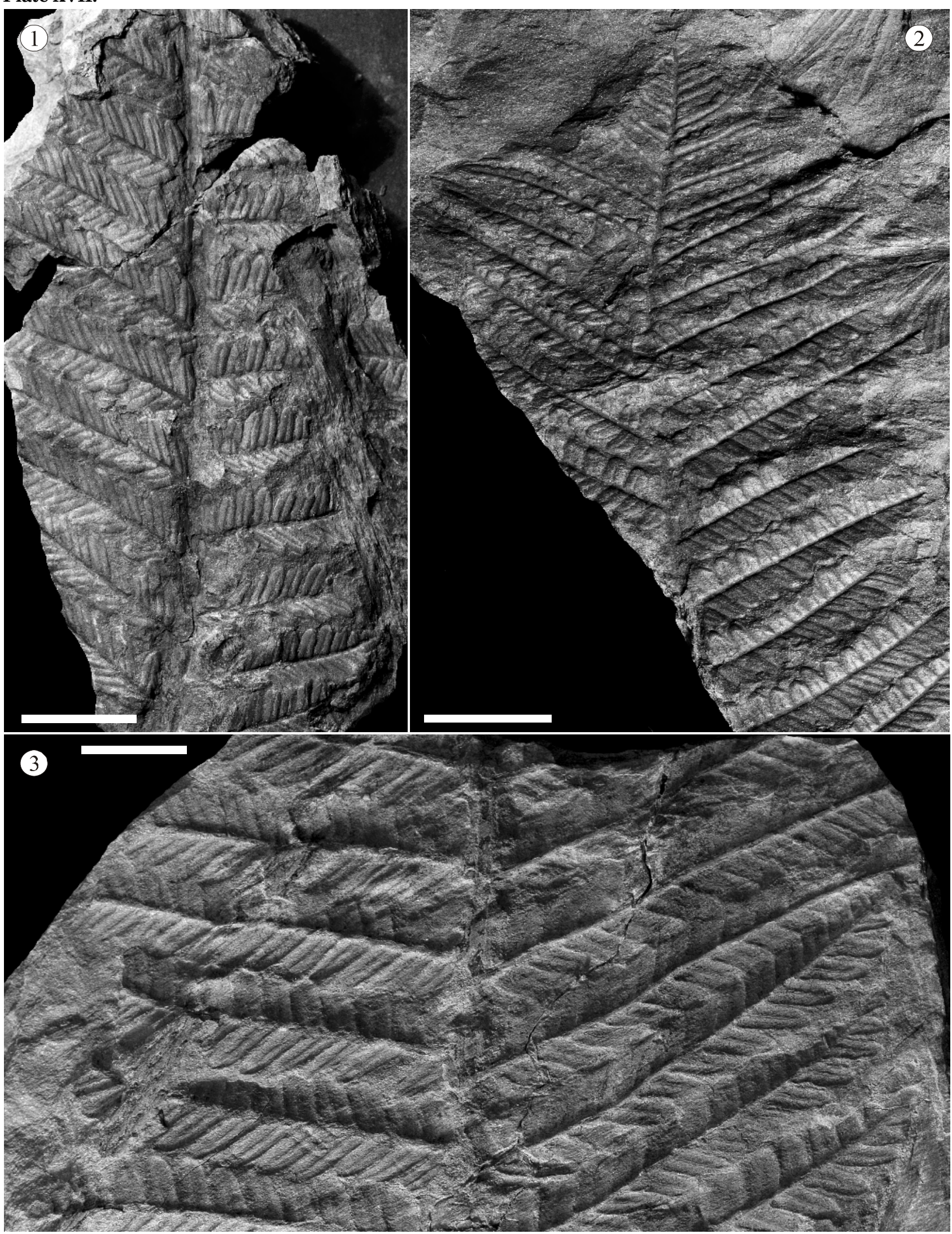
Folia vol. 48, No. 1-2, 2014

\section{Plate XVIII.}

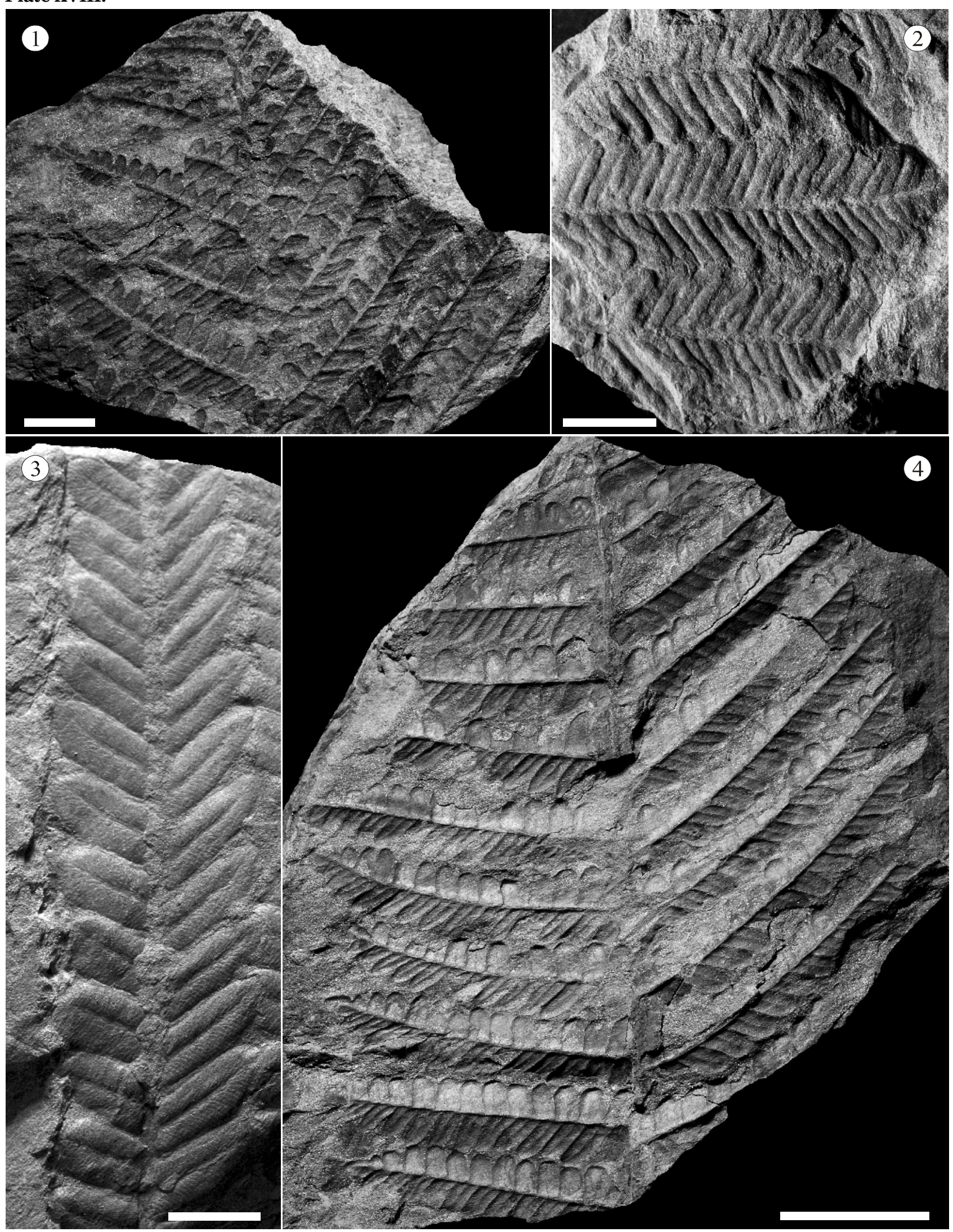




\section{Plate XIX.}
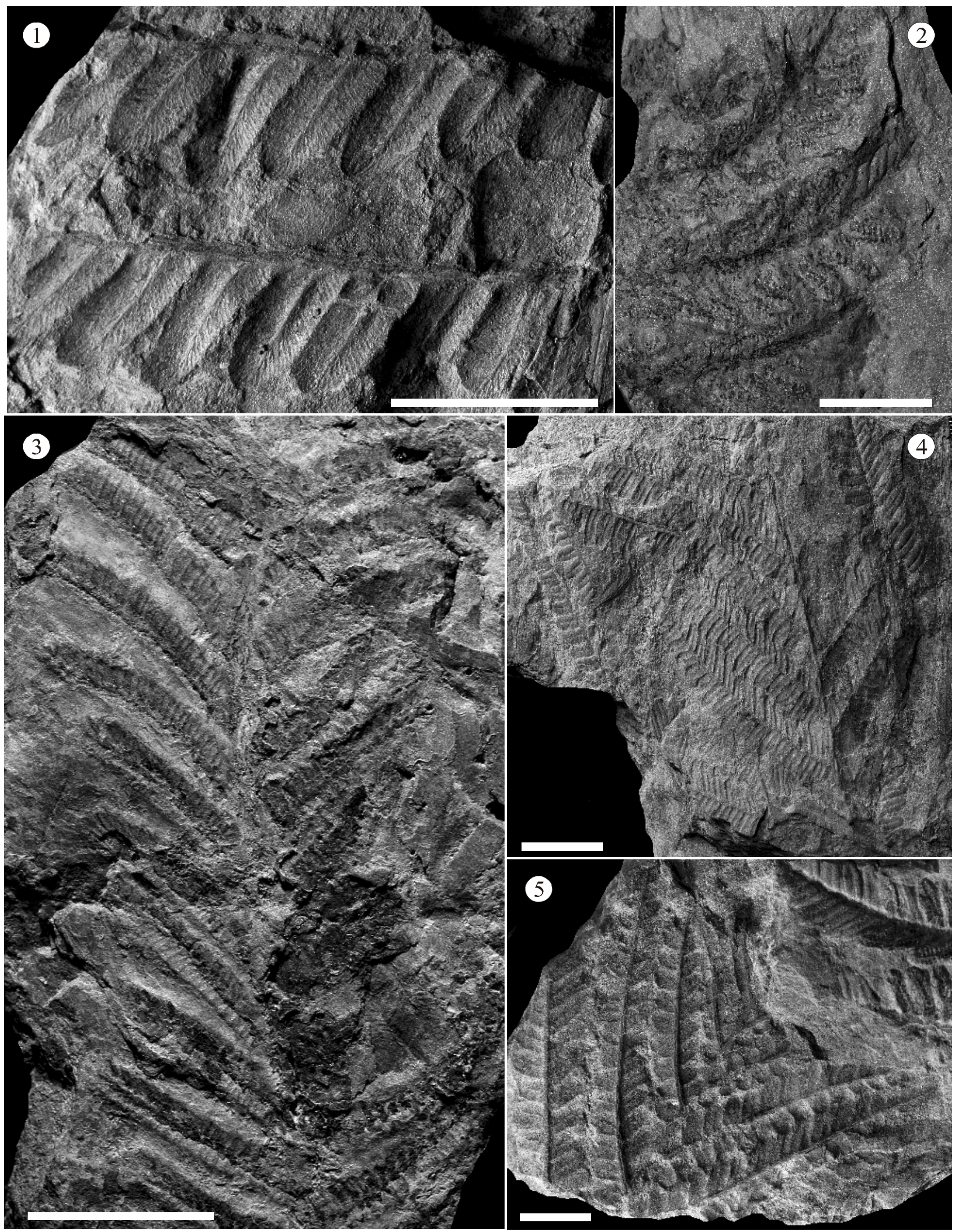


\section{Plate XX.}

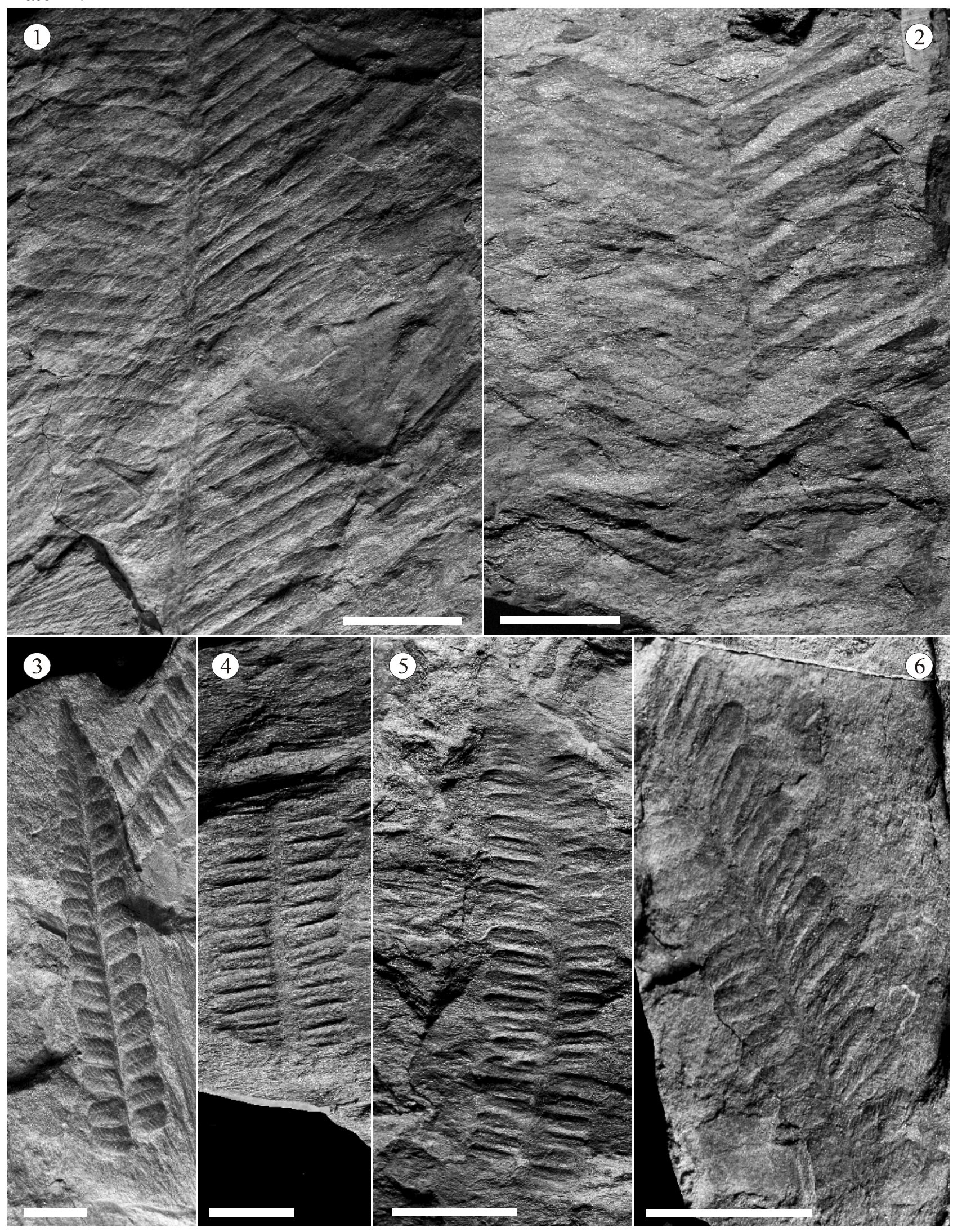


Species Pecopteris lepidorachis Brongniart (Plate XX, Figs 4-6)

This species is represented by only a few sterile specimens which came from both localities. Specimens show fragments of ultimate pinnae. Pinnae are more than $40 \mathrm{~mm}$ long. The ultimate rachis is punctuate, $1 \mathrm{~mm}$ broad. Pinnules are $1.5 \mathrm{~mm}$ wide and 5 - $6 \mathrm{~mm}$ long, little inclined (nearly the right angle) to ultimate rachis, touching together by pinnule sides (Plate XX, Figs 4, 5), not decurrent, sometimes the pinnule bases are slightly constricted (Plate XX, Fig. 6 arrow). The pinnules have parallel margins and are terminated in an obtuse tip. The midvein is marked to nearly the pinnule tip. Lateral veins dichotomize once near the midvein (Figure 3).

Remarks: The species shows similarities to $P e$ copteris arborescens (Schlotheim) Brongniart or Pecopteris cyathea (Schlotheim) Brongniart. The main differences between Pecopteris lepidorachis and these species are follow: Pecopteris arborescens has more or less simple lateral veins (Corsin, 1956; Barthel, 1980) and Pecopteris cyathea has sometimes more than once dichotomized lateral veins (Corsin, 1956) while between Pecopteris lepidorachis has one dichotomized lateral veins. Nevertheless, Pecopteris lepidorachis and Pecopteris cyathea are not easily distinguishable, especially when the venation is not well preserved.

\section{Species Pecopteris sp. (Plate XX, Fig. 3)}

This is interesting specimen which represents the apical part of ultimate pinna. The ultimate rachis is $0.5 \mathrm{~mm}$ broad. Linguaeform pinnules are $2 \mathrm{~mm}$ wide and $3 \mathrm{~mm}$ long. Venation is strong and well visible. Midvein is clearly marked to the rounded tip of the pinnules. Lateral veins are clearly marked and always simple (Figure 4). The pinna gradually tapers toward the more or less sharp tip (Plate XX, Fig.3).

Remarks: Pecopteris sp. has a quite different venation pattern in comparison to the previously described species Pecopteris lepidorachis. A similar venation pattern can be observed in Pecopteris arborescens. However, the distal end of the ultimate pinna of Pecopteris sp. is more or less sharp while types of Pecopteris arborescens show blunt tip of ultimate pinna (see Barthel, 1980, Plate I, Fig. 1). A similar comparison is possible between Pecopteris sp. and Pecopteris cyathea. The ultimate pinnae of Pecopteris cyathea have a blunt tip (Barthel, 1980, Plate III, Fig. 9) and lateral veins are forked, in contrast to the pinnae that have a more or less sharp tip and simple lateral veins of the studied species Pecopteris sp. Another similarity could be found with Pecopteris hemitelioides Brongniart. Both species (Pecopteris hemitelioides and Pecopteris sp.) have strongly marked, simple lateral veins. Nevertheless, the tip of ultimate pinna of Pecopteris hemitelioides is similar to those of Pecopteris cyathea and Pecopteris arborescens (see Corsin, 1951).

Plate XVIII. Acitheca polymorpha, all specimens come from Planina pod Golico locality; 1) Incomplete apical part of sterile penultimate pinna with smaller pinnules; specimen stored in drawer TJ9; scale bar $10 \mathrm{~mm}$; 2) Small specimen with incomplete ultimate pinna with small apical pinnule which is differentiated from the adjacent lateral pinnules; specimen stored in drawer TJ10; scale bar $10 \mathrm{~mm}$; 3) Part of ultimate pinna with typically linguaeform pinnules; specimen No. 3; specimen stored in drawer TJ9; scale bar $5 \mathrm{~mm}$; 4) Incomplete apical part of sterile penultimate pinna; specimen stored in drawer TJ10; scale bar $20 \mathrm{~mm}$.

Plate XIX. Acitheca polymorpha, specimens 1-3 and 5 come from Planina pod Golico locality, specimen 4 comes from Javorniški Rovt locality; 1) Detail from Plate XVII, figure 1. Linguaeform pinnules with polymorphopterid venation.; loc; specimen No. 4; specimen stored in exposition; scale bar $10 \mathrm{~mm}$; 2) Fertile specimen with folded pinnules bearing synangia; specimen stored in drawer TJ1; scale bar $10 \mathrm{~mm}$; 3) Fertile specimen with clearly visible long synangia; specimen No. 19; specimen stored in drawer TJ9; scale bar $10 \mathrm{~mm}$; 4) Part of penultimate pinna; specimen stored in drawer TJ2; scale bar $20 \mathrm{~mm}$; 5) Terminal part of penultimate pinna with small pinnules; specimen stored in drawer TJ1; scale bar $10 \mathrm{~mm}$.

Plate XX. All specimens come from Planina pod Golico locality; 1) Pecopteris victoriae; sterile part of ultimate pinna with long pinnules; specimen stored in drawer TJ1; scale bar $10 \mathrm{~mm}$; 2) Pecopteris victoriae; fertile specimen which shows a part of ultimate pinnae with long pinnules; specimen stored in drawer TJ9; scale bar $10 \mathrm{~mm}$; 3) Pecopteris sp.; terminal part of sterile ultimate pinna. The pinna gradually tapers toward the more or less sharp tip; scale bar 5 mm; 4) Pecopteris lepidorachis; sterile ultimate pinnae; specimen stored in drawer TJ1; scale bar $5 \mathrm{~mm}$; 5) Pecopteris lepidorachis; sterile ultimate pinnae; specimen stored in drawer TJ9; scale bar $10 \mathrm{~mm}$; 6) Pecopteris lepidorachis; sterile ultimate pinnae which is partly deformed; specimen stored in drawer TJ9; scale bar $10 \mathrm{~mm}$. 


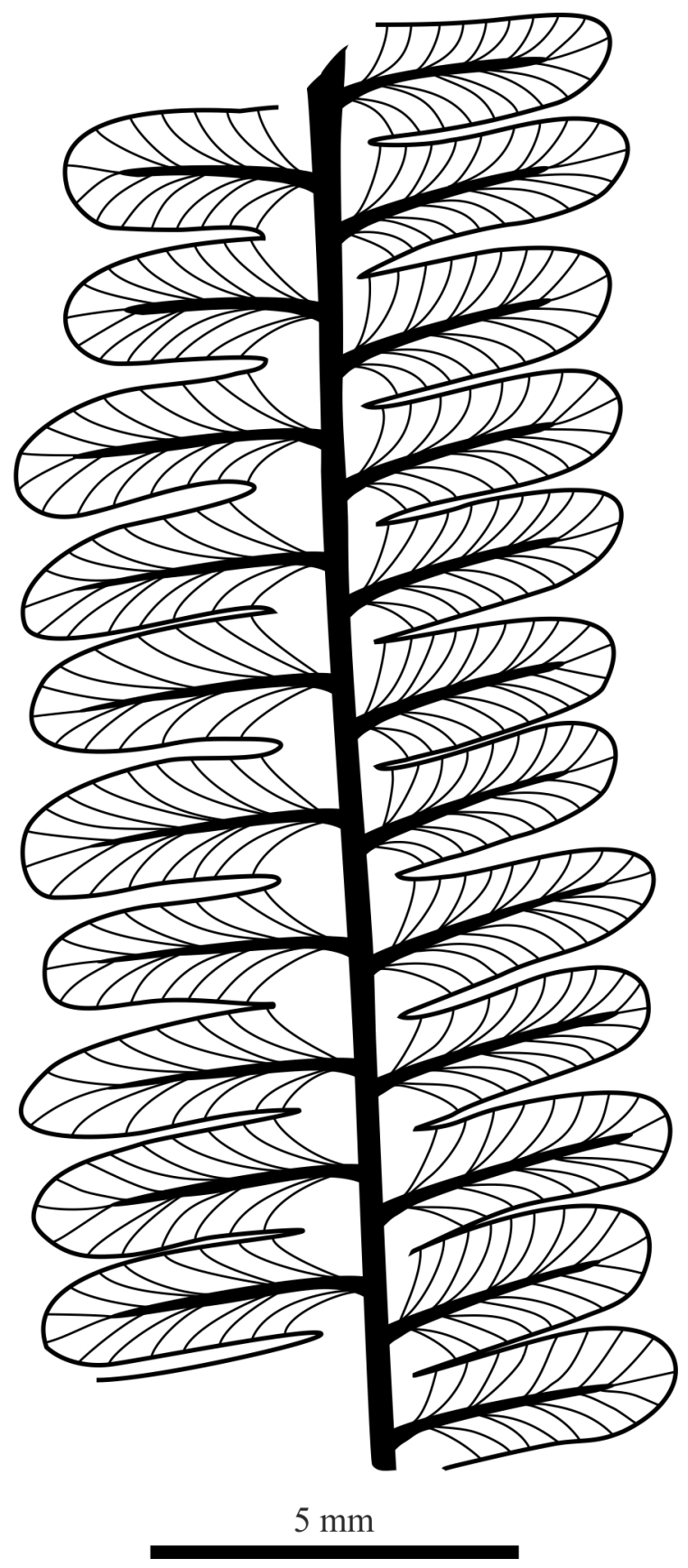

Figure 3. Venation diagram of pinnules of Pecopteris lepidorachis.

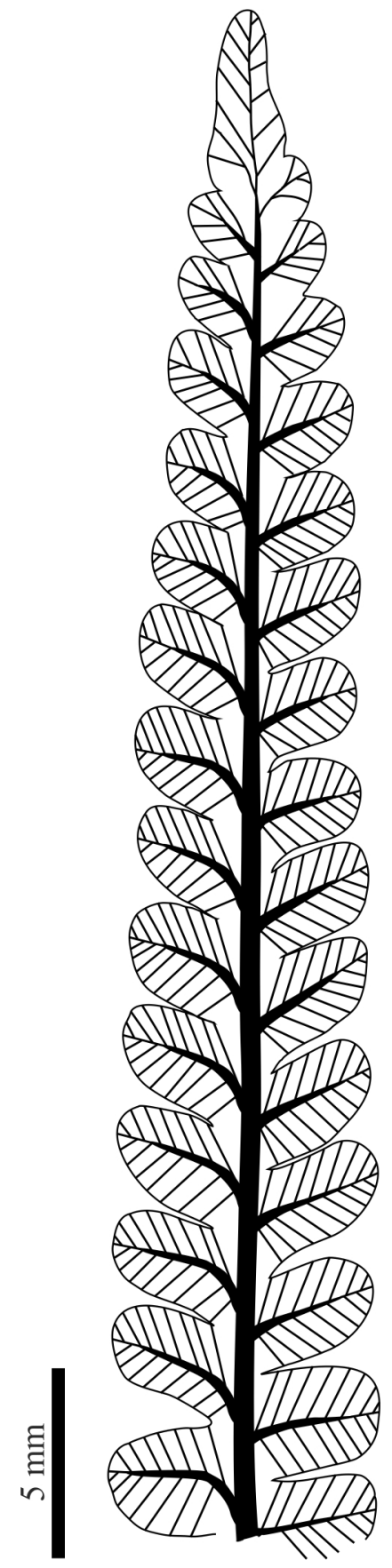

Figure 4. Venation diagram of pinnules of Pecopteris sp.

Plate XXI. Specimens 1, 3 and 4 come from Planina pod Golico locality, specimen 2 comes from Javorniški Rovt locality; 1) Pecopteris opulenta; fragment of penultimate pinna with small pinnules; specimen stored in drawer TJ3; scale bar 10 mm; 2) Lobatopteris polypodioides; part of penultimate pinna with partly united pinnules to each other in the basal part; specimen No. 12; specimen stored in drawer TJ2; scale bar $10 \mathrm{~mm}$; 3) Remia cf. pinnatifida; fragment of penultimate pinna. Four ultimate pinnae bearing sterile pinnatifid pinnules with strong midvein; specimen stored in drawer TJ1; scale bar 10 mm; 4) Remia cf. pinnatifida; apical part of penultimate pinna with entire-margined pinnules near the pinnae apices; specimen stored in drawer TJ9; scale bar $10 \mathrm{~mm}$. 


\section{Plate XXI.}

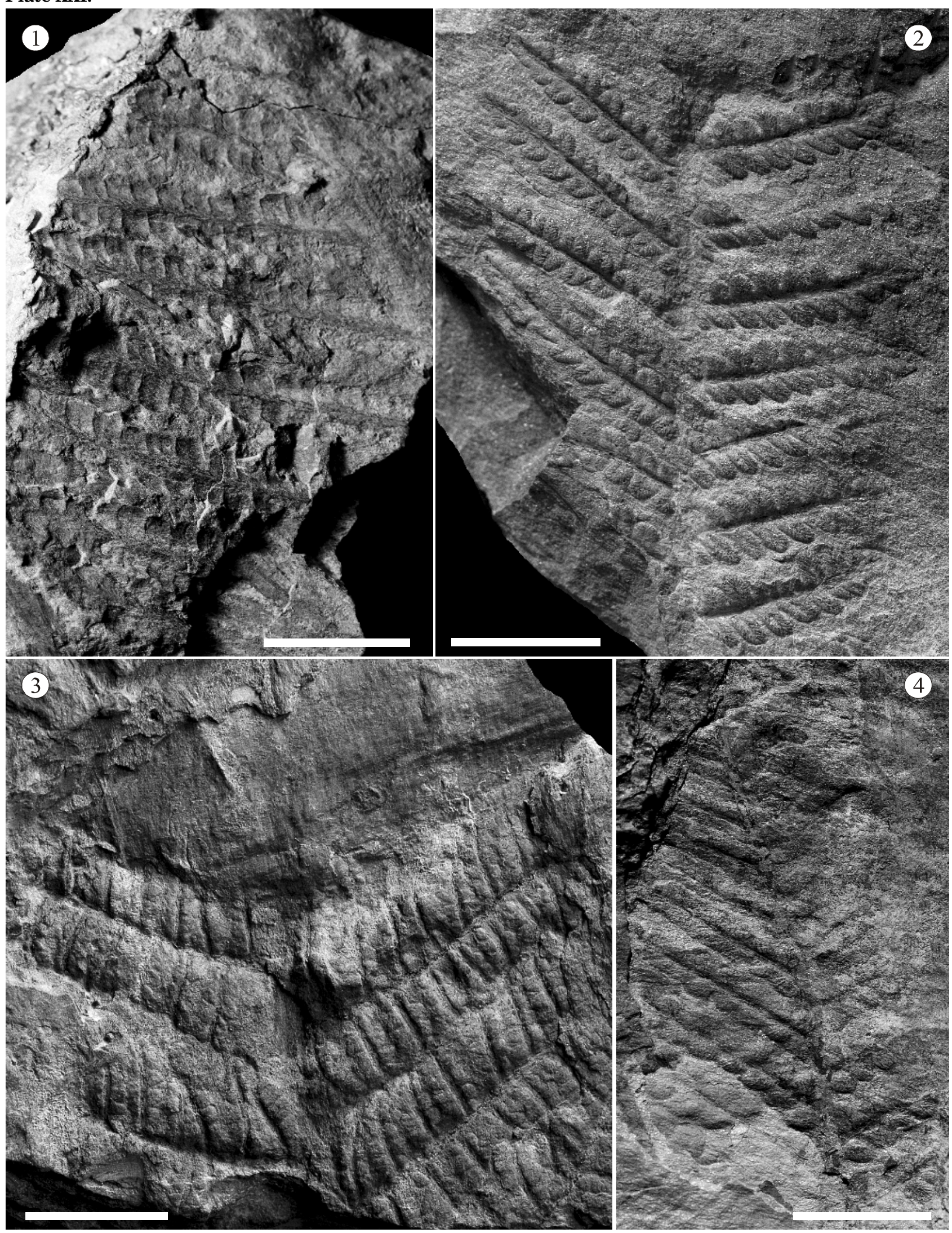


Species Pecopteris cf. opulenta Corsin (Plate XXI, Fig. 1)

One specimen shows great differences from the other pecopterid species and is referred to Pecopteris opulenta. The specimen represents part of a penultimate pinna with several incomplete ultimate pinnae. The penultimate rachis is $4 \mathrm{~mm}$ wide. Ultimate pinnae are parallel side, more than $25 \mathrm{~mm}$ long. The tip of an ultimate pinna is not present in any part of specimen. The ultimate rachis is $1 \mathrm{~mm}$ broad, longitudinally striated. Pinnules are $2.2 \mathrm{~mm}$ long and $2 \mathrm{~mm}$ wide, adherent to the base (weakly contracted upper margin, lower edge a little constricted), very slightly inclined to the support rachis, parallel side margins terminating in a broadly rounded tip. The midvein is not so prominent. Lateral veins are more than one times divided, more or less polymorphopterid type.

Remarks: The specimen corresponds with the description of Pecopteris oplunta published by Corsin (1951) on page 295-298. Nevertheless, only one poorly preserved specimen was discovered in the studied area.

\section{Subfamily Miltonoidae}

Lobatopteris polypodioides (C. Presl in Sternberg) Němejc (Plate XXI, Fig. 2)

Several sterile specimens represent Lobatopteris polypodioides which is also known from many Carboniferous localities through the world (especially in USA or Europe). The species is described only from Javorniški Rovt locality. This species is represented by part of a penultimate pinna. Penultimate rachises are straight, punctate, $1.6 \mathrm{~mm}$ broad. Ultimate pinnae are $17 \mathrm{~mm}$ long and 3 $5 \mathrm{~mm}$ wide, alternating, attached at $60^{\circ}$ to the supporting rachis.

Pinnules alternate, partly united to each other in their basal part, $1.5-2.5 \mathrm{~mm}$ long and $2 \mathrm{~mm}$ wide, with obtuse apex. Midvein straight, markedly curved at the base, extending to the apex, dividing into two veins at apical part sometimes divided once again. Lateral veins prominent, departing from midvein, one dividing in their lower part and sometimes divided once again.

Remarks: The variability and detailed description of this species was published by Pšenička (2005) and the description corresponds with the studied specimens. Fertile specimens are not discovered.
Family Incertae sedis

Species Remia cf. pinnatifida (Gutbier) Knight (Plate XXI, Figs 3, 4)

Some sterile specimens from the Planina pod Golico locality show great similarities with the species Remia pinnatifida. The largest specimen (Plate XXI, Fig. 3) shows a fragment of penultimate pinna with four ultimate pinnae. Penultimate rachis robust, $2.5 \mathrm{~mm}$ broad. Ultimate pinnae are more than $20 \mathrm{~mm}$ long with ultimate rachis $1.2 \mathrm{~mm}$ broad. Sterile pinnules are pinnatifid $4-5 \mathrm{~mm}$ long and $3 \mathrm{~mm}$ wide, with slightly constricted bases and rounded pinnule apices. The small pinnules near the pinnae apices are entiremargined (Plate XXI, Fig. 4 arrow) and towards to base the margins become lobate. The midvein is strong (0.6 mm wide) (Figure 5). Lateral veins several time bifurcating.

Remarks: The specimens are poorly preserved. Nevertheless, the venation is visible, especially the strong midvein on the pinnatified pinnules, which is a typical feature for this species (Kerp et al., 1991). Fertile pinnules were not observed, and so we are using confer with this species. Some similarities in the pinnules could also be found with Dicksonites pluckenetii, but the really strong midvein is atypical for that species.

\section{Caulopteris sp. (Plate XXII, Figs 3, 4)}

The specimen shows the impression of a stem which is related to marattilean plants. One leaf scar is preserved on the specimen. The leaf scar is elliptical, entirely isolated, the longer axis $100 \mathrm{~mm}$ and the shorter axis $40 \mathrm{~mm}$. The trace of vascular tissue is not visible. The scar is partly covered by aerial roots.

Remarks: The species is comparable with $\mathrm{Cau}$ lopteris species with large leaf scars published by Pfefferkorn (1976) under the name Caulopteris sp. D. This artificial genus is still waiting for general revision. Due to the fact, that we discovered more than one marattialean species, it is not possible to match this stem to one of those species. 


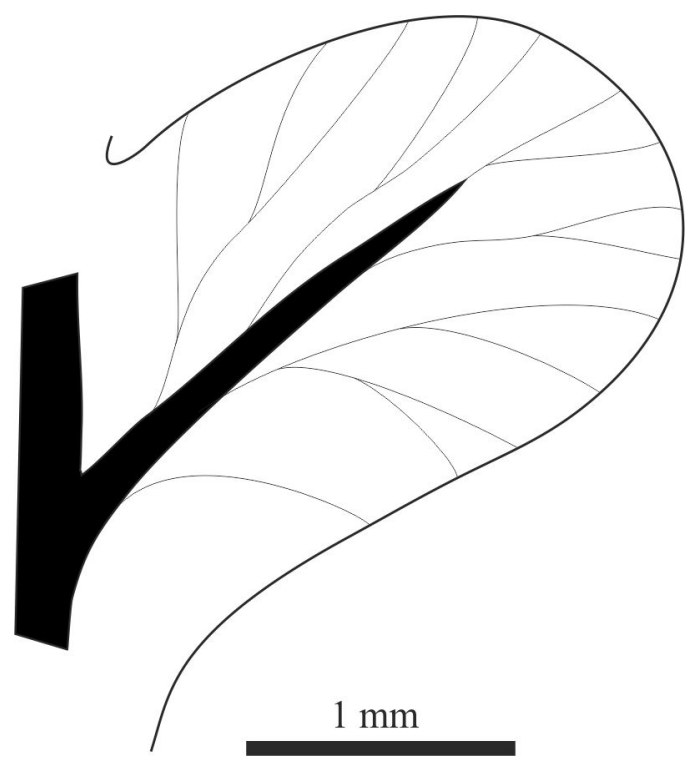

Figure 5. Venation diagram of pinnule of Remia $c f$. pinnatifida from studied locality.

Class Incertae sedis

Order Incertae sedis

Family Incertae sedis

Species Aphlebia sp. (Plate XXII, Figs 1, 2)

Aphlebias are common at both studied localities but very poorly preserved. Aphlebia sp. is represented by a large foliar segment more than $70 \mathrm{~mm}$ long. The margin of the aphlebiae are not well preserved, but appear to be entire (Plate XXII, Fig. 2) or ragged (Plate XXII, Fig. 1).

Remarks: Classification of aphlebian remains is very artificial. Most of them are classified based on their shape. Aphlebiae are known from pteridosperms as well as from ferns or cycads. The question is to which species the aphlebia belonged? Due to the fact the any pteridosperm are not know from studied localities, the aphlebia can belong to some species of marattilean plants.

Class Incertae sedis

Order Incertae sedis

Family Incertae sedis

Species Taeniopteris cf. jejunata Grand'Eury (Plate XXIII, Fig.1)

The specimen comes from Planina pod Golico locality. The specimen has several incomplete leaves that are more than $32 \mathrm{~mm}$ long and $9 \mathrm{~mm}$ wide, and parallel-side. The apex is not visible. The midvein is strong. Lateral veins are not well visible, coming from the midvein at $45^{\circ}$ and quickly running to the margin at nearly right angles.

Remarks: This species is well known from the Manebach Formation (Rotlingen) in Germany. Barthel et al. (1975) well revised this species and fragment published in this paper more or less corresponds with his figured specimens. Nevertheless, due to the fact that we have only fragment of leaves, the comparison is difficult.

This artificial species represents a heterogeneous group of leaves which are member of ferns, pteridosperms as well as cycads (Taylor et al., 2009). As we have only one sterile specimen, we cannot decide which plant group this species represents.

Class Cordaitopsida sensu Taylor and Taylor, 1993

Order Coraitales

Family Incertae sedis

Species Artisia sp. (Plate XXIII, Fig. 2)

This species is represented by one small specimen of a cordaite pith cast which is $15 \mathrm{~mm}$ wide. The pith cast is transversally septationed, which is typical for this genus.

Remarks: The presence of Artisia documents that cordaitalean plants were part of the palaenvironment. Nevertheless, the leaves have not been discovered.

\section{DISCUSSION}

\section{Composition of fossil flora}

The studied flora from both localities is typified by the occurrence of calamitalean plants and a high diversity of marattialean plants. Significant is the absence of any pteridosperms from the large Gornjesavski Muzej collection from both localities, which contain Many hundreds orf specimens. Nevertheless, in the past, Takšić (1947) and Morlot (1850) published a list (but did not figure) of several pteridosperms species from the studied area such as Alethopteris serlii Brongniart, Alethopteris grandini Brongniart, Alethopteris defrancii Goeppert, Neuropteris ovata Hoffmann and Neuropteris sp. Their results do not correspond with our observation. The question is, what is the cause of this major discrepancy in the floras represented in 
Folia vol. 48, No. 1-2, 2014

\section{Plate XXII.}

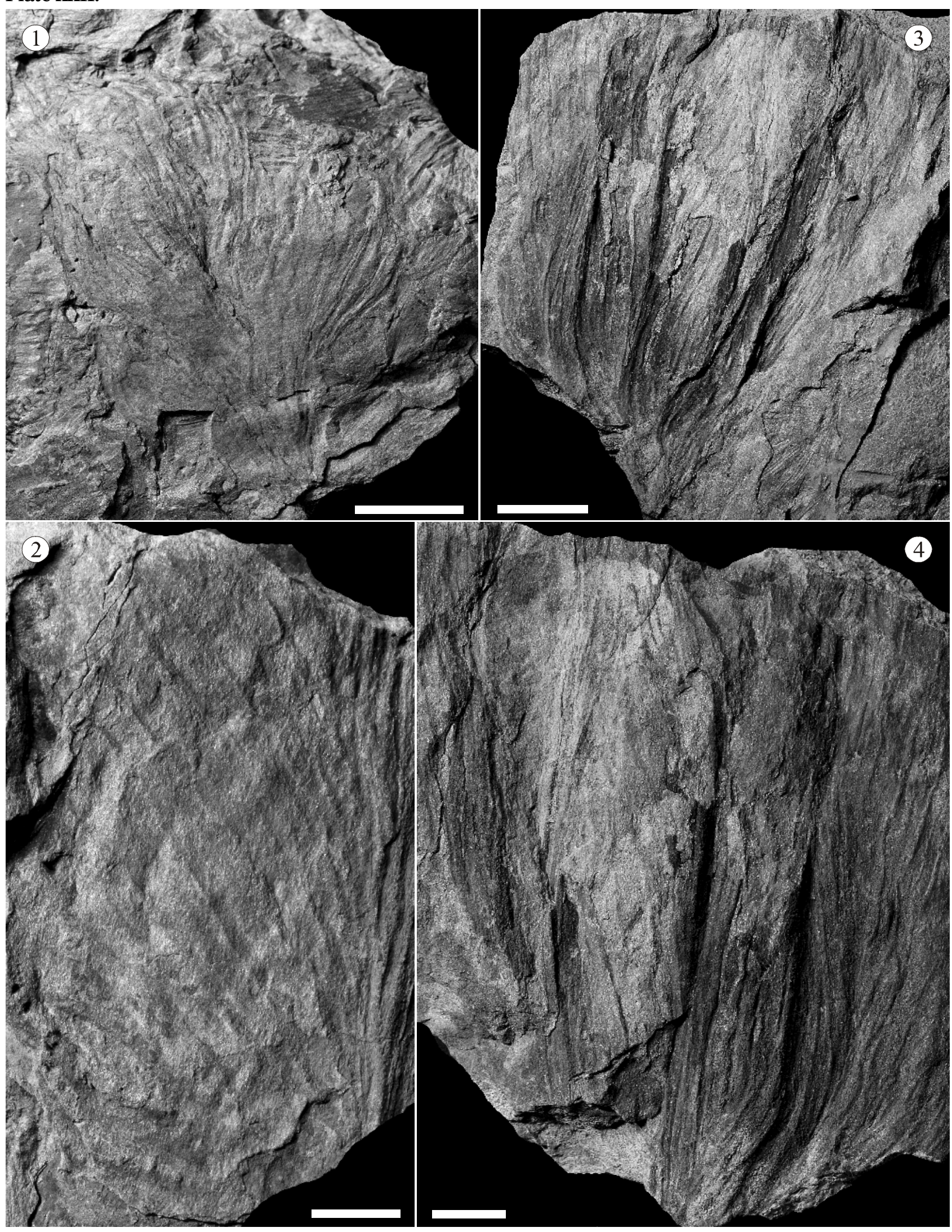




\section{Plate XXIII.}

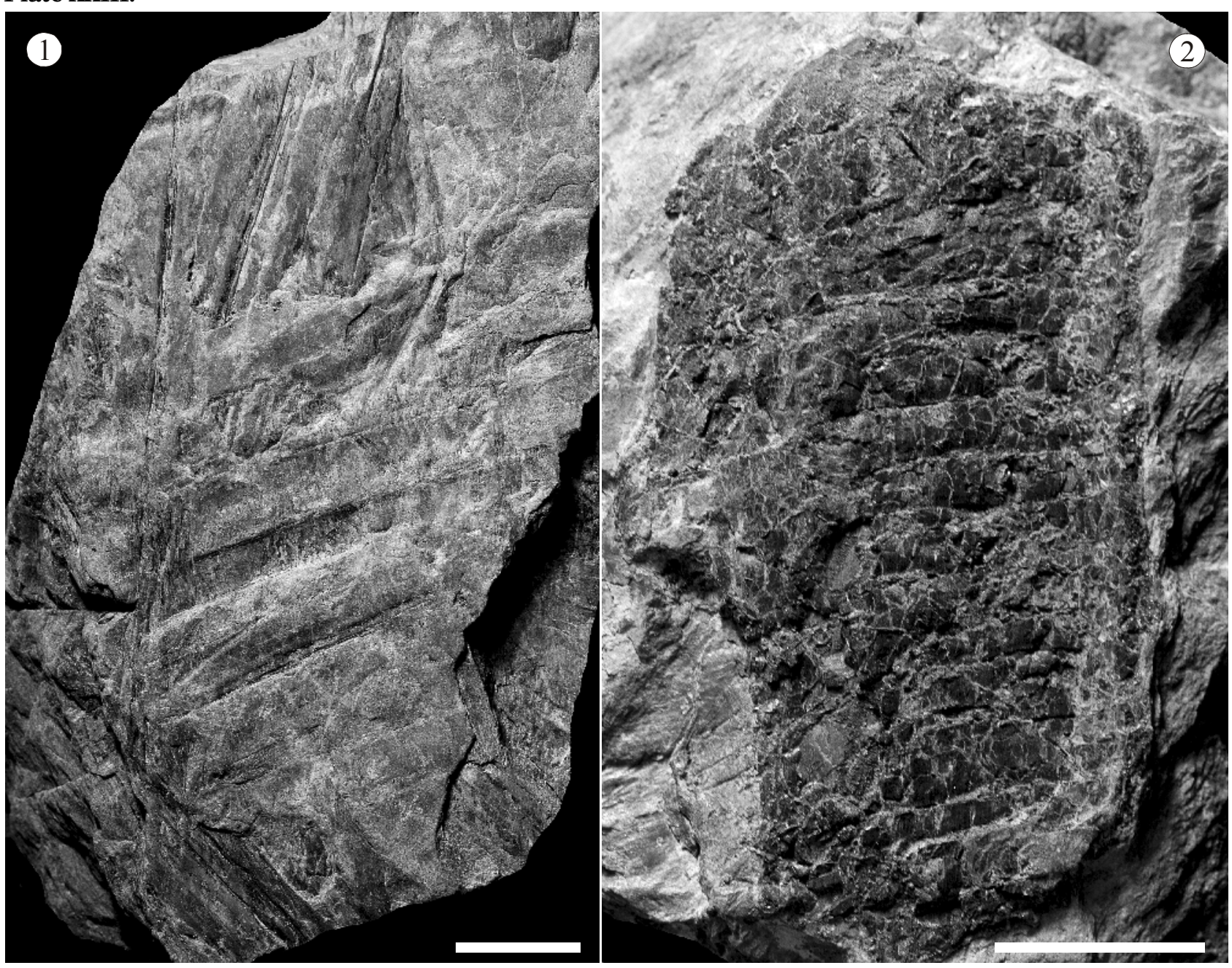

Plate XXIII. All specimens come from Planina pod Golico locality; 1) Taeniopteris sp.; specimen is represented by several incomplete leaves; specimen stored in drawer TJ9; scale bar $10 \mathrm{~mm}$; 2) Artisia sp.; specimen of cordaite pith cast with septate pith; specimen stored in drawer TJ3; scale bar $10 \mathrm{~mm}$.

the collection in Gornjesavski Muzej and in the list of species published by Takšić (1947) and Morlot (1850) Takšić (1947) and Morlot (1850) could have made some misclassifications. We can speculate that some large pinnules of Acitheca polymorpha could be misinterpreted as Alethopteris (especially, when pinnae are not well preserved), or some lobatopteris marattilean ferns can be mis- interpreted as Neuropteris. The problem is that Takšić (1947) and Morlot (1850) did not figure the specimens and so their classification of species cannot be checked. The Takšić (1947) material was collected by F. Šuklje, who gave it to Takšić to study it in detail, but its subsequent fate is unknown. Another reason for this floral discrepancy could be human bias. The specimens from the

Plate XXII. Specimens 1, 3, and 4 come from Planina pod Golico locality, specimen 3 comes from Javorniški Rovt locality; 1) Aphlebia sp.; specimen is represented by a large foliar segment; specimen stored in drawer TJ3; scale bar $10 \mathrm{~mm}$; 2) Aphlebia sp.; specimen is represented by a large foliar segment; specimen stored in drawer TJ2; scale bar 10 mm; 3) Caulopteris sp.; specimen shows impression of a stem. The leaf scar is elliptical with visible aerial roots; specimen stored in drawer TJ9; scale bar $10 \mathrm{~mm}$; 4) Caulopteris sp.; specimen shows impression of a stem. The leaf scar is elliptical with visible aerial roots; specimen stored in drawer TJ9; scale bar $10 \mathrm{~mm}$. 
area studied in the present paper were collected by Jože Bedič, who may have collected only visually well-preserved specimens, and small not visually well-preserved specimens were overlooked. Alternatively, Jože Bedič s localities may just not have contained pteridosperms, whereas they had accumulated in the same strata in other localities (i.e. there was lateral variation in the composition of the fossil flora). However, it is clearly difficult at this stage to verify such statements.

Stur (1886) also mentioned some species which come from studied area. Stur (1886) stated that the most frequent species from the area are the following: Pecopteris arguta Brongniart, P. pteroides Brongniart and Cordaites sp. Brongniart's Pecopteris arguta represents the same plant which nowadays is known under the name Nemejcopteris feminaeformis. The second species mentioned by Stur (1886), Pecopteris pteroides, could be compared with Lobatopteris polypodioides, which we describe in this paper from the studied area. Stur (1886) did not mention any species now regarded as pteridosperms, which corresponds with our observation. A minor difference is that Stur (1886) recorded abundant cordaitalean remains, whereas in our material there is only one small specimen of Artisia.

Based on our observation, the most common species are the following: Sigillaria brardii, Annularia carinata, Calamites (sensu lato), Acitheca polymorpha and Nemejcopteris feminaeformis (see Table 1). The fossil remains of calamitalean plants are really common. They are represented by compressed or partly three-dimensionally preserved casts of stems and adpressions of leaves. Two artificial types of calamitalean casts are presented. Both types probably belonged the same parent plants. Broader stems are identified as Calamites undulatus and are of the Stylocalaites-type. These are accompanied by narrower axes without significant undulation of canals (described in this paper under the name Calamites sp.) but which we assume are the narrower axes/branches of Calamites undulatus. The probability that both types of axis belong to one natural species is supported by the fact that only one type of sterile leaves Annularia carinata and one type of calamitalean reproductive organ Calamostachys cf. germanica occurred in the studied area.

Marattialean ferns are represented by seven fossil-species distinguished on the basis of the type of leaves. In some species we discovered sterile and fertile specimens (Acitheca polymorpha, Pecopteris victoriae), but others are known only as sterile remains. In contrast to many pecopterids fossilspecies, only one type of stem was discovered (Caulopteris sp.). This type of stem has been referred to the genus Acitheca (Zodrow et al., 2006). Therefore this type of stem can belong to other leaf species.

Clear gymnosperm plants are presented by only of a pith cast with transversal septation, belonging to the cordaitalean fossil-gernus Artisia. Cordaitalean leaves were not discovered in the collection.

\section{Biostratigraphy}

Wagner (1984) and Wagner and Alvarez-Vázquez (2010) established floristic biozones for the Upper Pennsylvanian Series. Stratigraphically important species from the study area are Sphenophyllum oblongifolium and Nemejcopteris feminaeformis (Galtier and Daviero, 1999; Barthel, 1968). Based on the occurrence of these species we can assume a stratigraphical position for the studied paleoflora of Gzhelian (Stephanian C to Autunian substages). Nevertheless, the absence of biostratigraphically important species (Wagner, 1984; Wagner and Alvarez-Vázquez, 2010) does not allow for a more precise assignment of the studied paleoflora to a single biozone. Therefore only the marine fauna associated with the plant-bearing strata can be used for determination of a more precise stratigraphic position. Kochansky-Devidé and Ramovš (1966) and Kochansky-Devidé (1971) described from these marine sediments in the broader Jesenice area (assigned to the Javornik Beds) a rich assemblage of fusulinid foraminifera indicating a Gzhelian age. This determination is not in contradiction with the presence of the stratigraphically wide range plant species including Sphenophyllum oblongifolium and Nemejcopteris feminaeformis. This position corresponds to the Autunia conferta or Annularia spicata biozones of Wagner and Álvarez-Vázquez (2010), although neither of these two stratigraphically important species have not been reported from the study area. This high stratigraphic position is also not in contradiction with the relatively common occurrence of arborescent lycopsid remains. They belong to Bergeria dilatata, a species typical for the West- 
phalian Stage. Its occurrence, assuming the correct identification, in the upper Stephanian is therefore very unusual and represents the first report from such a high stratigraphic position. Another species, Lepidodendron dissitum is a typically late Westphalian and Stephanian species, reported even from late Stephanian (Stephanian C) strata of Spain (Wagner et al., 1985; Wagner and Talens, 1985). Fritz and Boersma (1983) reported this species as Lepidodendron aculeatum from the Carnic Alps, so its occurrence in the study localities is not surprising. Sigillaria brardii, the most common lycopsid, is a typical Stephanian taxon ranging throughout most of the Stephanian Stage and therefore in agreement with a Gzhelian age of the strata inferred from the associated fauna.

\section{Comparison with the Carnic Alps localities}

Based on the reported plant fossil bearing localities from the Carnic Alps (Unger, 1870; Fritz and Boersma, 1980, 1984a, 1984b, 1986a, 1986b, 1986c; Fritz et al., 1990; Krainer, 1989, 1990; Fritz and Krainer, 1995, 2004, 2006, 2007), we can infer a correlation with the Corona (Krone) Member of the Auernig Formation. However, it is true that the above mentioned authors made many misinterpretations of species, especially among the pecopterid group of plants. Therefore, some localities show similar fossil plant association with study area. One of these localities is Hüttengraben in Rattendorfer Alm (Austria). The paleoflora from this locality described by Fritz and Boersma (1986c) included 27 plant fossil taxa. The common species are following: Annularia carinata [Fritz and Boersma (1986c) misinterpreted this species as Annularia stellata and A. sphenophylloides], Nemejcopteris feminaeformis, Acitheca polymorpha, Pecopteris opulenta [Fritz and Boersma (1986c) misinterpreted this species as Pecopteris aff. miltonii] Taeniopteris sp. and remains of lycopsids and cordaitalean plants. Fritz and Boersma (1986c) also mentioned some pteridosperms as Alethopteris bohemica, Callipteridium gigas, C. pteridium, Odontopteris alpina, O. minor or Pseudomariopteris busquetii. All these species show affiliation to the Alethopteris zeillerii biozone [Stephanian B, "Saberian" sensu Wagner and Alvarez-Vázquez (2010)]. There are also great similarities with the fossil flora from the Schlanitzer Alm locality, from where
Fritz and Boersma (1984a) described 18 taxa. The species common to both this and the studied localities are the following: Annularia carinata [Fritz and Boersma (1984a) misinterpreted this species as Annularia stellata and A. sphenophylloides], Sphenophyllum oblongifolium, Syringodendron (our sigillarian species), cf. Lepidodendron, Acitheca polymorpha, Nemejcopteris feminaeformis and Artisia. Nevertheless, Fritz and Boersma (1984a) described also some pteridosperms sensu lato from this locality, but only one species Callipteridium pteridium. It means that this low occurrence or absence of pteridosperm-like plants is a common element from both areas. Based on these fossil floras it is still impossible to define an exact stratigraphical position, and we can only state that it is of Stephanian age.

\section{Comparison with Czech basins}

Plant assemblages of the localities in the vicinity of Jesenice, Slovenia, are typical of a Stephanian age, however, they lack the species necessary for a precise determination of the stratigraphic position to a single biozone. As stated above, a late Stephanian (late Gzhelian) age was therefore inferred from the associated marine fauna. Strata of this age occur in several basins in the Czech Republic (Pešek, 2004). In central and western Bohemia this stratigraphic level corresponds to the Líně Formation, which is a complex of fluvial red beds with intercalated grey lacustrine deposits bearing fossils. Its flora includes most of the species identified in the Slovenian material from Jesenice but includes also some other stratigraphically important species important for the determination of their precise stratigraphic position within the Sphenophyllum angustifolium Zone (Opluštil et al., 2013). The same can be stated for the late Stephanian Semily Formation in the Krkonoše-piedmont Basin in Sudetic area, NE Czech Republic. In the southern and eastern part of the country late Stephanian coal-bearing strata rich in plant fossils are present in the Blanice and especially in the Boskovice basins. The plant assemblages from there are also more diverse than the Slovenian fossil floras and include species important for a precise stratigraphic location within a single floral biozone. For an overview of the plant species of the Czech basins see Pešek (2004). 
Table 1. List of species documented from the studied localities.

\begin{tabular}{|c|c|c|c|c|c|}
\hline \multicolumn{3}{|c|}{ Plant groups } & \multirow{2}{*}{$\begin{array}{c}\text { Species } \\
\text { Lepidodendron dissitum }\end{array}$} & \multirow{2}{*}{$\frac{\begin{array}{c}\text { Planina } \\
\text { pod Golico }\end{array}}{X X X}$} & \multirow[t]{2}{*}{$\begin{array}{c}\text { Javorniški } \\
\text { Rovt }\end{array}$} \\
\hline Lycopsida & & \multirow{4}{*}{$\begin{array}{c}\text { Stem } \\
\quad / \\
\text { shoots }\end{array}$} & & & \\
\hline & & & Bergeria cf. dilata & $x x$ & \\
\hline & & & Knorria sp. & $x x$ & \\
\hline & & & Sigillaria brardii & $X X X X$ & \\
\hline & & $\begin{array}{l}\text { Leafy } \\
\text { shoots }\end{array}$ & Annularia carinata & $X X X$ & $x x$ \\
\hline \multirow{4}{*}{ Sphenopsida } & \multirow{3}{*}{$\begin{array}{c}\text { Equisetales } \\
\text { (Calamitaceae) }\end{array}$} & Cones & Calamostachys tuberculata & $x$ & \\
\hline & & Stems & Calamites (Stylocalamites) undulatus & $X X X$ & \\
\hline & & & Calamites sp. & $x X$ & \\
\hline & \multicolumn{2}{|c|}{ Sphenophyllales } & Sphenophyllum oblongifolium & $x x$ & \\
\hline \multirow{9}{*}{ Pteridopsida } & \multirow[t]{8}{*}{ Marattiales } & \multirow[t]{7}{*}{ Leaves } & Acitheca polymorpha & $X X X$ & $X X X$ \\
\hline & & & Pecopteris victoria & $x$ & \\
\hline & & & Pecopteris lepidorachis & $x X$ & $\mathrm{x}$ \\
\hline & & & Pecopteris sp. & $x$ & \\
\hline & & & Pecopteris opulenta & $x$ & \\
\hline & & & Lobatopteris polypodioides & & $X X X$ \\
\hline & & & Remia pinnatifida & $\mathrm{X}$ & \\
\hline & & Stems & Caulopteris sp. & $x$ & $x$ \\
\hline & \multicolumn{2}{|c|}{ Zygopteridales } & Nemejcopteris feminaeformis & $x X$ & $X X X$ \\
\hline \multicolumn{3}{|c|}{ Gymnospermophyta } & & & \\
\hline Cordaitopsida & Cordaites & Stems & Artisia sp. & $\mathrm{X}$ & \\
\hline \multicolumn{3}{|c|}{ Insertae sedis } & & & \\
\hline & & & Taeniopteris jejunata & $\mathrm{X}$ & \\
\hline & & & Aphlebia sp. & $\mathrm{X}$ & $\mathrm{x}$ \\
\hline \multicolumn{4}{|c|}{ Number of morphospecies (root and decorticates neglected) } & 20 & 7 \\
\hline \multicolumn{4}{|c|}{ Estimated number of biological species } & 15 & 4 \\
\hline
\end{tabular}

\section{ACKNOWLEDGEMENTS}

This paper is supported by grant project $\mathrm{P} 210 / 12 /$ 2053 provided by the Grant Agency of the Czech Republic and Slovenian Research Agency (program P1-0011). We would like to thank to Mr. Milan Peternel who provided us useful information on fossil sites and guided one of us (MN) in the field.
Another thanks go to Ronny Roessler and Robert $\mathrm{H}$. Wagner for consulting with identification of fossil plants.

The paper is a contribution to the IGCP-Project 575 "Pennsylvanian terrestrial habitats and biotas of southeastern Euramerica". 


\section{REFERENCES}

Álvarez-Vazquez, C., Wagner, R.H. 2014. Lycopsida from the lower Westphalian (Middle Pennsylvanian) of the Maritime Provinces, Canada. Atlantic Geology 50, 167-232.

Barthel, M. 1968. "Pecopteris" feminaeformis (Schlotheim) Sterzel, und "Araucarites" spiciformis Andrae in Germar - Coenopterideen des Stephans und Unter Perms. Paläontologische Abhandlungen Abteilung B, Paläobotanik, II, 4, 635-793.

Barthel, M. 1980. Pecopteris-Arten E.F. von Schlotheims aus Typuslokalitäten in der DDR. Zeitschrift für Geologische Wissenschaften, Berlin, 16, 275-304.

Barthel, M. 2000. Annularia stellata oder Annularia spinulosa? Veröffentlichungen Naturkundemuseum Erfurt, 19, 37-42.

Bek, J., Opluštil, S., Drábková, J., Pšenička, J. 2014. The sub-arborescent lycopsid Omphalophloios feistmantelii (O. Feistmantel) comb. nov. emend. from the Middle Pennsylvanian of the Czech Republic. Bulletin of Geosciences, 90(1), 227-279.

Boureau, E. 1964. Traité de Paléobotanique. III. Sphenophyta Noeggeratiophyta. Masson, Paris, $544 \mathrm{pp}$.

Buser, S. 1980. Tolmač lista Celovec (Klagenfurt), Osnouna geološka karta SFRJ 1:100000 / Explanationary notes on the sheet of Celovec (Klagenfurt), Basic geologic map SFR Yugoslavia 1:100000. Zvezni geološki zavod, Beograd, $62 \mathrm{pp}$.

Buser, S. 2009. Geološka karta Slovenije = Geological map of Slovenia. 1:250 000. Geološki Zavod Slovenije, Ljubljana.

Forke, H. C. 2002. Biostratigraphic Subdivision and Correlation of Uppermost Carboniferous/ Lower Permian Sediments in the Southern Alps: Fusulinoidean and Conodont Faunas from the Carnic Alps (Austria/Italy), Karavanke Mountains (Slovenia), and Southern Urals (Russia). Facies, 47, Erlangen, 201-276.

Fritz, A., Boersma, M. 1980. Fundberichte über Pflanzenfossilien aus Kärnten 1980, Beitrag 1: Pflanzliche Großreste aus dem Oberkarbon der Krone, Karnische Alpen. Carinthia II, 170/90, 221-238.

Fritz, A., Boersma, M. 1984a. Fundberichte über Pflanzenfossilien aus Kärnten 1984, Beitrag 7: Schlanitzer Almweg (Stefan), Karnische Alpen. Carinthia II, 1974/94, 21-35.
Fritz, A., Boersma, M. 1984b. Fundberichte über Pflanzenfossilien aus Kärnten 1984, Beitrag 9: Krone (Stefan), Karnische Alpen. Carinthia II, 1974/94, 145-175.

Fritz, A., Boersma, M. 1986a. Fundberichte uber Pflanzenfossilien aus Karnten 1986, Beitrag 11: Tomritsch-Rucken (Unterstefan) Karnische Alpen. Carinthia II, 176/96, 69-85.

Fritz, A., Boersma, M. 1986b. Fundberichte uber Pflanzenfossilien aus Karnten 1986, Beitrag 13: Hüttengraben (Ober-Stefan) Rattendorfer Alm, Karnische Alpen. Carinthia II, 176/96, 241-262.

Fritz, A., Boersma, M. 1986c. Fundberichte uber Pflanzenfossilien aus Karnten 1986, Beitrag 14: Zollnersee (Unterstefan) Karnische Alpen. Carinthia II, 176/96, 147-165.

Fritz, A., Boersma, M., Krainer, K. 1990. Steinkohlenzeitliche Pflanzenfossilien aus Kärnten. Carinthia II, Sonderheft 49, 192 pp.

Fritz, A., Krainer, K. 1995. Die Megafloren Tomritsch-3 und Tomritsch- 6 aus den oberkarbonen Auernigschichten der Karnischen. Carinthia II, 185/105, 553-583.

Fritz, A., Krainer, K. 2004. Pflanzenfossilien aus den Grenzlandbanken der Rattendorfer Alm (Karnten, Karnische Alpen). Carinthia II, 194/114, 445-454.

Fritz, A., Krainer, K. 2006. Vegetationsgeschichtliche und florenstratigraphische Untersuchungen im Oberkarbon und Unterperm der Ost- und Sudalpen (Teil 1). Carinthia II, 196/116, 93-120.

Fritz, A., Krainer, K. 2007. Vegetationsgeschichtliche und florenstratigraphische Untersuchungen im Oberkarbon und Unterperm der Ost- und Sudalpen (Teil 2). Carinthia II, 197/117, 91-148.

Galtier, J., Daviero, V. 1999. Structure and development of Sphenophyllum oblongifolium from the Upper carbpniferous of France. International Journal of Plant Science,160/5, 1021-1033.

Gensel, P.G., Pigg, K.B., 2009: An arborescent lycopsid from the Lower Carboniferous Price Formation, southwestern Virginia, USA and the problem of species delimitation. International Journal of Coal Geology, 83, 132-145.

Hauer, F.V. 1851. Nachricht über die Sammlung in Laibach. Mitteilungen von Freunden der Naturwissenschaften, 7(4), 139-140.

Heritsch, F. 1931. Versteinerungen aus dem Karbon der Karawanken und Karnischen Alpen. Abhandlungen der Geologische Bundesanstalt A., 23, 3, 56 pp. 
Heritsch, F., Kahler, F. \& Metz, K. 1934. Die Schichtfolge von Oberkarbon und Unterperm, 163-180. In Heritsch, F. (ed.), Die Stratigraphie von Oberkarbon und Perm in den Karnischen Alpen. Mitteilungen der Geologische Gesellschaft. 26 (1933).

Jongmans, W.J. 1932. Fossilium Catalogus II: Plantae: Pars 18. Lycopodiales IV. Kluwer Academic Publishers, Berlin, 658-996..

Jongmans, W.J., Dijkstra, S.J. 1969. Fossilium Catalogus II: Plantae. Pars. 74. Lycopodiales IX. Kluwer Academic Publishers, Berlin, 15511659 .

Jurkovšek, B. 1987. Tolmač lista Beljak in Ponteba, Osnovna geološka karta SFRJ 1:100000 / Explanationary notes on the sheets of Beljak (Villach and Pontebba), Basic geologic map SFR Yugoslavia 1:100000. Zvezni geološki zavod, Beograd, 58 pp.

Kahler, F. 1955. Entwicklungsräume und Wanderwege der Fusulinen im Eurasiatischen Kontinent. Geologie 4, 179-188.

Kahler, F. 1986. Ein Normalprofil der FusulinidenStratigraphie im Oberkarbon und Unterperm der Karnischen Alpen. Carinthia II 176/96, 1-17.

Kerp, J.H.F., Poort, R.J., Swinkles, H.A.J.M., Verwer, R. 1991. An emendation of the genus Remia Knight - Acase of a realistic classification of Late Palaeozoic plant megafosils. Review of Palaeobotany and Palynology, 67, 199-203.

Kochansky-Devidé, V. 1965. Die ältesten Fusulinidenschichten Sloweniens. Geološki vjesnik 18/2, 333-336.

Kochansky-Devidé, V. 1971. Mikrofosili in biostratigrafija zgornjega karbona $\mathrm{v}$ zahodnih Karavankah. Razprave 4. razr. SAZU XIV/6, 205-211.

Kochansky-Devidé, V., Ramovš, A. 1966. Zgornjekarbonski mikrofosili in stratigrafski razvoj v zahodnih Karavankah. Razprave 4. razr. SAZU 9, 299-333.

Kolar-Jurkovšek, T., Jurkovšek, B. 1985. Nova nahajališča paleozojske flore $\mathrm{v}$ Posavskih gubah med Ljubljano in Litijo. Razprave IV. Razr. SAZU 26, 199-218.

Kolar-Jurkovšek, T., Jurkovšek, B. 1986. Karbonska (westfalijska) makroflora iz Zavrstnika. Rudalsko metalurski zbornik, 33(1-2), 3-34.
Kolar-Jurkovšek, T., Jurkovšek, B. 1990. Karbonska makroflora med Jančami in Polšnikom v Posavskih gubah. Rudalsko metalurski zbornik, 37(3), 367-389.

Kolar-Jurkovšek, T., Jurkovšek, B. 2002a. Karbonski gozd. Karbonske plasti $z$ rastlinskimi fosili pri Ljubljani (Carboniferous Forest. Carboniferous strata with plant fossils near Ljubljana). Geološki zavod Slovenije, Ljubljana, $191 \mathrm{pp}$.

Kolar-Jurkovšek, T., Jurkovšek, B. 2002b. Rastlinski fosili v karbonskih plasteh na trasi avtoceste pri Bizoviku. Geologija 45(2), 433-438. Doi: 10.5474/geologija.2002.044.

Kolar-Jurkovšek, T., Jurkovšek, B. 2007. Zgornjekarbonska flora Grajskega hriba v v Ljubljani (Late Carboniferous flora of Castle Hill in Ljubljana, Slovenia). Geologija 50(1), 9-18. Doi: 10.5474/geologija.2007.001.

Kolar-Jurkovšek, T., Jurkovšek, B. 2012. Late Carboniferous floras from Slovenia - a review. Geologia Croatica, 65(3), 323-328.

Kossmat, F. 1913. Die adriatische Umrandung in der alpinen Faltenregion. Mitteilungen der Geologischen Gesellschaft, 6, 61-165.

Krainer, K. 1989. Das Karbon in Kärnten. Carinthia II, 179./99, 59-109.

Krainer, K. 1990. Die basalen Auernigschichten am Tomritsch-Rücken südlich von Tröpolach (Oberkarbon, Karnische Alpen, Kärnten). Jahrbuch der Geologischen Bundesanstalt-A, 133, 567-574.

Krainer, K. 1992. Fazies, Sedimentationsprozesse und Paläogeographie im Karbon der Ostund Südalpen. In Neuergebnisse aus dem Paläozoikum der Ost- und Südalpen. Jahrbuch der Geologischen Bundesanstalt-A, 135/1, 99-193.

Krainer, K., Davydov, V. 1998. Facies and biostratigraphy of the Late Carboniferous/Early Permian sedimentary sequence in the Carnic Alps (Austria/Italy). In Crasquin-Soleau, S., Izart, A. Vaslet, D., De Wever, P. (eds.), PeriTethys: stratigraphic correlations 2 . Geodiversitas, 20/4, 643-662.

Massari, F., Venturini, C. 1990. The significance of the Auernig Group cyclicity. In Venturini, C. (ed.) Field workshop on Carboniferous to Permian sequence of the Pramollo-Nassfeld Basin (Carnic Alps) (September 2-8, 1990), Guidebook. Arti Grafiche Friulani, 81-86. 
Lee, H.H. 1963. Fossil plants of the Yeuhmenkou Series, North China. Paleontologica Sinica, NSA, 6, 1-185

Lipold, M. V. 1857. Bericht über die geologischen Aufnahmen in Oberkrain im Jahre 1856. Jahrbuch der Geologischen Reichsanstalt, 8, 205-234.

Lipold, M. V. 1858. Bericht über die geologischen Aufnahmen in Unter-Krain im Jahre 1857. Jahrbuch der Geologischen Reichsanstalt, 257-276.

Morlot, H. 1850, Über die geologischen Verhältnisse von Oberkrain. Jahrbuch der Geologischen Reichsanst, 1 (3), 389-411.

Němejc, F. 1953. Taxonomical studies on the fructifications of the Calamitaceae collected in the coal district of Central Bohemia. Acta Musei Nationalis Prague B, Geologia et palaeontologia, 9/1, 1-62.

Novak, M. 2007a. Biostratigrafija mlajšega paleozoika Dovžanove soteske (Biostratigraphy of Late Paleozoic beds in the Dovžanova soteska). 159 pp. Ph. D. Thessis, Naravoslovnotehniška fakulteta, Univerza v Ljubljana.

Novak, M. 2007b. Depositional environment of Upper Carboniferous - Lower Permian in Karavanke Mountains (Southern Alps, Slovenia). [Sedimentacijsko okolje zgornjekarbonskih in spodnjepermskih plasti v Karavankah (Južne Alpe, Slovenija)]. Geologija, 50/2, 247-268. Doi: 10.5474/geologija.2002.018.

Novak, M., Skaberne, D. 2009. Upper Carboniferous and Lower Permian, 99-136. In Pleničar, M., Ogorelec, B., Novak, M. (eds.), The Geology of Slovenia, Geološki zavod Slovenije, Ljubljana.

Opluštil, S., Šimůnek, Z., Zajíc, J., Mencl, V. 2013. Climatic and biotic changes around the Carboniferous/Permian boundary recorded in the continental basins of the Czech Republic. International Journal of Coal Geology, 119, 114-151.

Pavšič, J. 1995. Fosili, zanimive okamnine iz Slovenije. Tehniška založba Slovenije, 139 pp.

Pešek, J. 2004. Late Palaeozoic limnic basis and coal deposits of the Czech Republic. Folia Musei Rerum Naturalium Bohemiae Occidentalis, Geologica, 1, 1-188.

Pšenička, J. 2005. Taxonomy of Pennsylvanian ferns from Permo-Carboniferous Coal basins in the Czech republic and Canada. $\mathrm{PhD}$ thesis, Charles University, Prague 2005, 185 pp.

Pšenička, J., Bek, J., Cleal, C.J., Wittry, J., Zodrow, E.L. 2009. Description of synangia and spores of the holotype of the Carboniferous fern Lobatopteris miltoni, with taxonomic comments. Review of Palaeobotany and Palynology, 155, 133-144.

Pfefferkorn, H.W. 1976. Pennsylvanian Tree Fern Compression Caulopteris, Megaphyton, and Artisophyton gen. nov. in Illinois. Illinois State Geological Suirvey, Urbana, circular, 492, 1-18.

Placer, L. 1999. Contribution to the macrotectonic subdivision of the border region between Southern Alps and External Dinarides. Geologija, 41, 223-255. Doi: 10.5474/geologija.1998.013.

Rakovec, I. 1932. H geologiji Ljubljane in njene okolice. Geogr. vest. 8/1-4: 38-70.

Ramovš, A. 1978. Okamnelo življenje v jeseniškem prostoru. (Versteinertes Leben im Gebiet von Jesenice). Techniški muzej Železarne Jesenice, $81 \mathrm{pp}$.

Schönlaub, H. P., Forke, H. C. 2007. Die postvariszische Schichtfolge der Karnischen Alpen. - Erläuterungen zur Geologischen Karte des Jungpaläozoikums der Karnischen Alpen 1 : 12500. Abhandlungen der Geologische Bundesanstalt-A, 61, 3-157.

Selli, R. 1963. Schema geologico delle Alpi Carniche e Giulie occidentali. Giornale de Geologia, 30 (2), 1-121.

Stur, D. 1886: Oberkarbonische Pflanzenreste von Bergbau Reichenberg bei Assling in Oberkrain. - Verh. Geol. R.-A. 15, 383-385, Wien.

Takšić, A. 1947. Prinos poznavanju gornjokarbonske flore Golice (Karavanke). = Contribution to the knowledge of the Upper Carboniferous flora from Golica (Karavanken Mountains). Geološki vjesnik, 1, 232-240.

Tornquist, A. 1929. Die Blei-Zinklagestätte der Savefalten vom Typus Litija (Littai). Berg und Hüttenmann. Jahrbuch, 77(1), 1-28.

Unger, F. 1870. Anthrazit-Lager in Kärnten. Sitzungsber Österrich Akad. d. Wiss, 60, 6-10, 777-794.

Venturini, C. 1982. Il bacino tardoercinico di Pramollo (Alpi Carniche): un'evoluzione regolata dalla tettonica sinsedimentaria. Memoir Society of Geologia Italia, 24, 23-42, Roma. 
Wagner, R. H., 1958a. Pecopteris pseudo-bucklandi Andrae and its generical affinities. Mededelingen van de Geologische Stichting, New Series $12,25-30$.

Wagner, R.H. 1984. Megafloral zones of the Carboniferous. Compte rendu 9e Congrčs International de Stratigraphie et de Géologie du Carbonifčre (Washington, 1979) 2, 109-134.

Wagner, R.H., Alvarez-Vázquez, C. 2010. The Carboniferous floras of the Iberian Peninsula: a synthesis with geological connotations. Review of Palaeobotany and Palynology 162, 239-324.

Wagner, R.H., Talens, J. 1985. On the upper Westphalian and Stephanian species, Lepidodendron dissitum Sauver, 435-444. In M.J.L. Sousa and R.H. Wagner (Eds.) Papers on the Carboniferous of Iberian Penninsula (Sedimentology, Stratigraphy, Paleontology, Tectonics and Geochronology). Anais da Faculdade de ciencias do Porto., Supplementa, 64.

Zodrow, E.L. 1989. Revision of Silesian sphenophyll biostratigraphy of Canada. Review of Palaeobotany and Palynology, 58, 301-331

Zodrow, E.L., Šimůnek, Z., Cleal, C.J., Bek, J., Pšenička, J. 2006. Taxonomic revision of the Palaeozoic marattialean fern Acitheca Schimper. Review of Palaeobotany and Palynology, 138, 239-280. 